NUREG/CR-0893

PNL-3046

\title{
Acute Toxicity and Bioaccumulation of Chloroform to Four Species of Freshwater Fish
}

Salmo gairdneri, Rainbow Trout

Lepomis macrochirus, Bluegill

Micropterus salmoides, Largemouth Bass

Ictalurus punctatus, Channel Catfish

Prepared by D. R. Anderson, E. B. Lusty

Pacific Northwest Laboratory

Operated by

Battelle Memorial Institute

Prepared for

U.S. Nuclear Regulatory

Commission 


\section{NOTICE}

This report was prepared as an account of work sponsored by an agency of the United States Government. Neither the United States Government nor any agency thereof, or any of their employees, makes any warranty, expressed or implied, or assumes any legal liability or responsibility for any third party's use, or the results of such use, of any information, apparatus product or process disclosed in this report, or represents that its use by such third party would not infringe privately owned rights.

\section{Available from}

GPO Sales Program

Division of Technical Information and Document Control

U. S. Nuclear Regulatory Commission Washington, D. C. 20555

Printed copy price: $\$ 3.50$

and

National Technical Information Service Springfield, Virginia 22161 
NUREG/CR-0893

PNL-3046

RE

\section{Acute Toxicity and Bioaccumulation of Chloroform to Four Species of Freshwater Fish}

Salmo gairdneri, Rainbow Trout

Lepomis macrochirus, Bluegill

Micropterus salmoides, Largemouth Bass

Ictalurus punctatus, Channel Catfish

Manuscript Completed: July 1980

Date Published: August 1980

Prepared by

D. R. Anderson, E. B. Lusty

Pacific Northwest Laboratory

Richland, WA 99352

\section{Prepared for}

Division of Safeguards, Fuel Cycle and Environmental Research

Office of Nuclear Regulatory Research

U.S. Nuclear Regulatory Commission

Washington, D.C. 20555

NRC FIN No. B2098 



\section{ABSTRACT}

Acute toxicity of chloroform to four species of freshwater fish was studied in flow-through 96-hr toxicity tests. Chloroform is toxic to fish in the tens of parts per million, a concentration well above that which would be expected to be produced under normal power plant chlorination conditions. Investigations of acute toxicity of chloroform and the bioaccumulation of chlorinated compounds in tissues of fish revealed differences in tolerance levels and tissue accumulations. Mean $96-\mathrm{hr} \mathrm{LC}_{50} \mathrm{~s}$ for chloroform were $18 \mathrm{ppm}$ for rainbow trout and bluegill, 51 ppm for largemouth bass and 75 ppm for channe 1 catfish. Mortalities of bluegill and largemouth bass occurred during the first $4 \mathrm{hr}$ of exposure while rainbow trout and channel catfish showed initial tolerance and mortalities occurred during the latter half of the 96-hr exposure. Rainbow trout had the highest level of chloroform tissue accumulation, $7 \mu \mathrm{g} / \mathrm{g}$ tissue, catfish the second highest, $4 \mu \mathrm{g} / \mathrm{g}$ tissue, followed by bluegill and largemouth bass which each accumulated about $3 \mathrm{~kg} / \mathrm{g}$ tissue. Accumulation of chloroform was less than one order of magnitude above water concentrations for all species. 

The acute toxicity of chloroform $\left(\mathrm{CHCl}_{3}\right)$ to four species of freshwater fish was studied in 28 flow-through 96-hr toxicity tests. Mean LC50 for each species is: rainbow trout (Salmo gairdneri) $18 \mathrm{ppm}$, bluegill (Lepomis macrochirus) $18 \mathrm{ppm}$, largemouth bass (Micropterus salmoides) $51 \mathrm{ppm}$ and channel catfish (Ictalurus punctatus) $75 \mathrm{ppm}$. Mortality of bluegill and largemouth bass occurred during the first $4 \mathrm{hr}$ of exposure while rainbow trout and channel catfish exhibited an initial tolerance to chloroform with mortality occurring during the latter half of the 96-hr test. Behavioral responses to chioroform were noted in rainbow trout and largemouth bass.

Chloroform accumulation/depuration studies consisting of 24-hr exposures to 1.0-1.5 ppm $\mathrm{CHCl}_{3}$ followed by $24 \mathrm{hr}$ of depuration were conducted on the same four species of fish. Of the four species of fish tested, rainbow trout accumulated the highest level of chloroform in the tissues, $7 \mu \mathrm{H} \mathrm{CHCl} / \mathrm{g}$ tissue. Catfish accumulated the next highest tissue concentration of chloroform at $4 \mu \mathrm{g} \mathrm{CHCl}_{3} / \mathrm{g}$ tissue, followed by bluegill and bass which each accumulated approximately $3 \mu \mathrm{g} \mathrm{CHCl} / 3 / 9$ tissue. Bioaccumulation of chloroform in these fish above the water concentration was less than one order of magnitude.

Bluegill apparently had higher tissue levels of chloroform after 4-hr exposure than after $24 \mathrm{hr}$ exposure to $1 \mathrm{ppm} \mathrm{CHCl}$. Rainbow trout and bass apparently reached maximum accumulation levels after $4 \mathrm{hr}$ of exposure. Catfish was the only species tested that had an apparent increase in tissue concentration of chlorof orm between the 4-hr and 24-hr sampling times. The bioconcentration factor in catfish cannot be determined from our data since tissue concentrations did not reach equilibrium within $24 \mathrm{hr}$.

The 96-hr $L_{50}$ s for each species are several orders of magnitude above the chloroform levels found in previous studies of chlorinated natural waters simulating power plant chlorination conditions across the U.S. Therefore, although chloroform is toxic to fish in the range of tens of parts per million, this amount is well above that which could be expected to be produced under normal power plant chlorination conditions.

Since chloroform has been classified by the Environmental Protection Agency as a carcinogen, further studies beyond 96-hr acute toxicity studies are needed to determine the environmental impact of chloroform entering the aquatic environment. Acute toxicity testing is a first step in determining the hazard of chloroform to fish. Evaluation of the environmental impact of chloroform should take into consideration the widespread and long-term use of chlorine and thus long-term production of chloroform by steam generating power plants across the United States. Other studies of long-term effects or effects of chloroform on reproduction, carcinogenicity, teratogenicity and mutagenicity are warrented given existing information in the literature. 



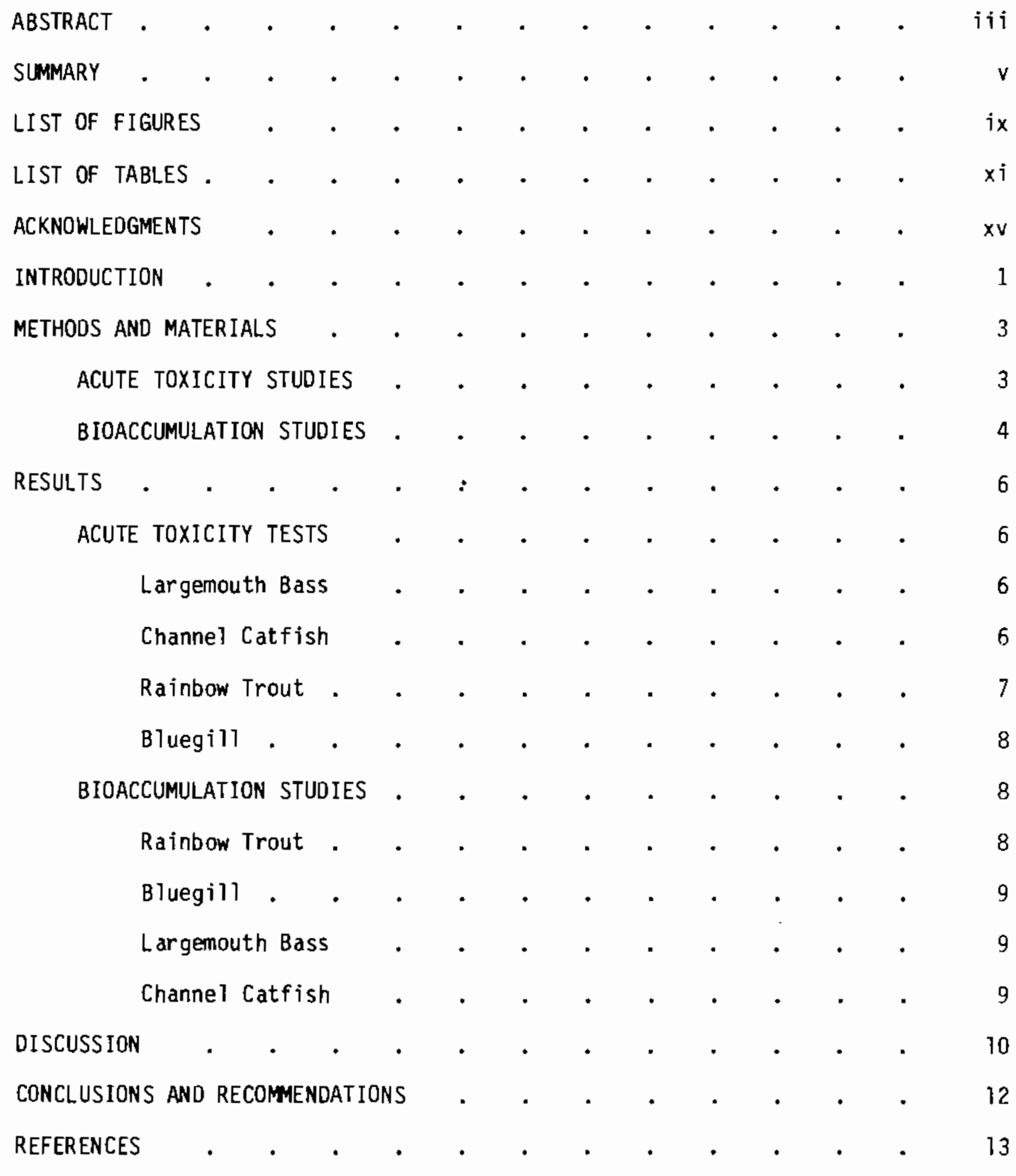





\section{LIST OF FIGURES}

1 Delivery System Used for Acute Chloroform Tests

of Freshwater Species .

2 Mortalities of Largemouth Bass During 96-hr Toxicity Tests

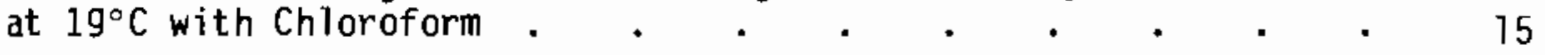

3 Mortalities of Channel Catfish During 96-hr Toxicity

Tests at $19^{\circ} \mathrm{C}$ with Chloroform . . . . . . . . 16

4 Mortalities of Rainbow Trout During 96-hr Toxicity Tests at $19^{\circ} \mathrm{C}$ with Chloroform . . . . . . . . . 17

5 Mortalities of Bluegill During 96-hr Toxicity Tests at $19^{\circ} \mathrm{C}$ with Chloroform . . . . . . . . . 18

6 Chloroform Concentrations in Rainbow Trout Exposed to

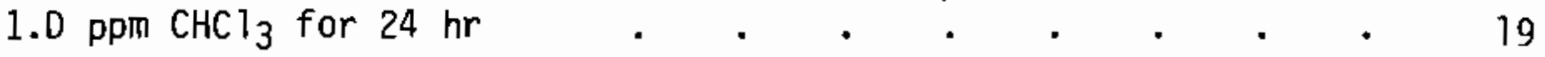

7 Chloroform Concentrations in Bluegill Exposed to $1.0 \mathrm{ppm}$

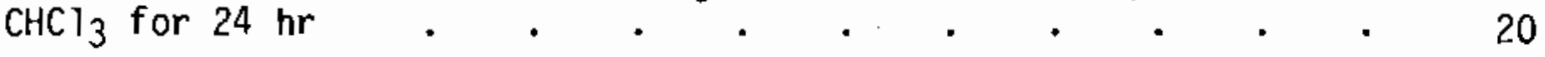

8 Chloroform Concentrations in Largemouth Bass Exposed to

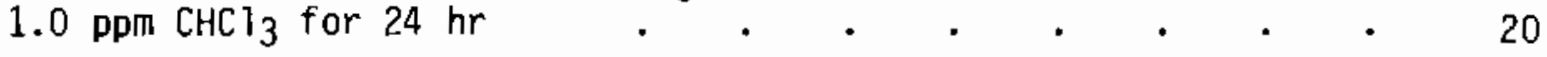

9 Chloroform Concentrations in Channel Catfish Exposed to $1.0 \mathrm{ppm} \mathrm{CHCl}_{3}$ for $24 \mathrm{hr}$ 



\section{LIST OF TABLES}

1 Mean Length and weight of Fish Used in $96 \mathrm{Hr}$

Chloroform Toxicity Tests

2 Chloroform Accumulation/Depuration in Rainbow Trout

During a $24-\mathrm{hr}$ Exposure to $1.0 \mathrm{ppm} \mathrm{CHCl}_{3} \mathrm{Follow}$

by $24 \mathrm{hr}$ of Depuration at $20.2^{\circ} \mathrm{C}$. . . . . . .

3 Chloroform Accumulation/Depuration in Bluegill During

a 24- $\mathrm{hr}$ Exposure to $1.0 \mathrm{ppm} \mathrm{CHCl}_{3}$ Followed by $3.0 \mathrm{hr}$

of Depuration at $26.3^{\circ} \mathrm{C}$

4 Chloroform Accumulation/Depuration in Largemouth Bass

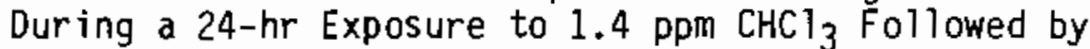

$24 \mathrm{hr}$ of Depuration at $23.4^{\circ} \mathrm{C}$.

5 Chloroform Accumulation/Depuration in Catfish During

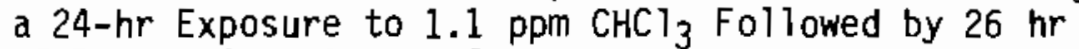
of Depuration at $24.3^{\circ} \mathrm{C}$

6 Acute $\mathrm{Ch}$ loroform $\mathrm{LC}_{50} \mathrm{~S}$ (ppm) with Largemouth Bass at $19^{\circ} \mathrm{C}$ in Columbia River Water . . . . . . .

7 Acute Chloroform $\mathrm{LC}_{50} \mathrm{~s}$ (ppm) with Channel Catfish at $19^{\circ} \mathrm{C}$ in Columbia River Water . . . . . .

8 Acute Chloroform $\mathrm{LC}_{50} \mathrm{~S}$ (ppm) with Bluegill at $25^{\circ} \mathrm{C}$ in Columbia River Water . . . . . . . . . . 28

9 Acute Chloroform $L C_{50} 5$ (ppm) with Rainbow Trout at $13^{\circ} \mathrm{C}$ in Columbiakiver Water . . . . . . . . . . . . 28

10 Largemouth Bass Mortalities During 96-hr Acute Toxicity Tests at 19:C with Chloroform . . . . . .

11 Channel Catfish Mortalities During 96-hr Acute Toxicity Tests with Chloroform

12 Rainbow Trout Mortalities During $96-\mathrm{hr}$ Acute

13 Bluegill Mortalities During 96-hr Acute Toxicity Tests with Chloroform 


\section{PREFACE}

This report includes data and analysis for the Freshwater Biology Task of the program on Biocide By-Products in Aquatic Environments.

Reports prepared for the entire program are:

Title

- Investigation of Halogenated Components Formed from Chlorination of Natural Waters: Preliminary Studies, NUREG/CR-1299

- Acute Toxicity and Bioaccumulation of Chloroform to Four Species of Fresh Water Fish Sa Imo gairdneri, Rainbow Trout Lepomis macrochirus, Bluegill Micropterus salmoides, Largemouth Bass Ictalurus punctatus, Channel Catfish, NUREG/CR-0893

- Chronic Effects of Chlorination By-Products on Rainbow Trout, Salmo gairdneri, NUREG/CR-0892

- Toxicity, Bioaccumulation and Depuration of Bromoform in Five Marine Species

Protothaca staminea, Littieneck Clam Mercenaria mercenaria, Eastern Hard Clam, Quahog Crassostrea virginica, Eastern oyster Penaeus aztecus, Brown Shrimp Brevoortia tyrannus, At lantic Menhaden, NUREG/CR-1297

- Growth and Histological Effects to Protothaca staminea, (Littleneck Clam) of Long-Term Exposure to Chiorinated Sea Water, NUREG/CR-1298

- Analysis of Organohalogen Products from Chlorination of Natural Waters Under Simulated Biofouling Control Conditions, NUREG/CR-1301

- Biocide By-Products in Aquatic Environments, Final Report Covering Period September 10, 1976 through September 30, 1979, NUREG/CR-7300
Author

Roger M. Bean

Robert G. Riley

David R. Anderson E. William Lusty

David R. Anderson Roger M. Bean Roger E. Schirmer

Charles I. Gibson Fredrick C. Tone Peter Wilkinson J. W. Blaylock Roger E. Schirmer

Charles I. Gibson Robert E. Hillman Peter Wilkinson Dana L. Woodruff

Roger M. Bean Dale C. Mann Robert G. Riley

Roger M. Bean Charles I. Gibson David R. Anderson 



\section{ACKNOWLEDGMENTS}

T. L. Page and R. M. Bean critically reviewed the manuscript. Naomi Sherer provided technical editing. Charles Stephan, U.S. EPA provided the computer program used to compute the $\mathrm{L}_{50}$ and $95 \%$ confidence interva1.

\section{DISCLAIMER}

Trade names and registered trademarks are used for reader convenience and their use does not imply endorsement by Battelle Memorial Institute or the Nuclear Regulatory Commission. 

A study on effects of chlorination by-products was undertaken on selected aquatic biota in freshwater and marine environments. 0bjectives of one phase of the study were to determine the acute toxicity and bioaccumulation of chloroform, a major freshwater chlorination by-product, to four species of freshwater fishes. Choice of chloroform as a toxicant was based on results of the analytical phase of the Chiorination By-Products Program. Studies conducted to determine the biologically available chlorinated organics produced from chlorination of freshwater across the United States indicated that chlorof orm was the major chlorination by-product produced in freshwater. Therefore we conducted acute $(96-h r)$ toxicity studies with rainbow trout (Salmo gairdneri), bluegill (Lepomis macrochirus), channel catfish (Ictalurus punctatus) and Targemouth bass (Micropterus salmoides). The species were selected because of their economic and ecological importance in aquatic ecosystems near power plants using freshwater as a secondary coolant. A major objective of the acute toxicity tests was to provide data for the evaluation of potential toxicity resulting from chloroform produced during power plant chlorination. Acute $96-\mathrm{hr} L C_{50}$ s were determined and compared to expected levels of chloroform produced during power plant chlorination.

Objectives of the bioaccumulation studies were: (1) to determine if chloroform bioaccumulates (2) to determine the level of bioaccumulation during shortterm exposures of fish to chloroform. One to two year old fish were used for bioaccumulation tests.

Previous experiments with marine species indicated that bromoform rapidly accumulated in animal tissues. This, along with the acute toxicity tests, suggested short term accumulation/depuration tests be conducted. A 24-hr exposure to chlorof orm followed by $24-\mathrm{hr}$ depuration was selected. 



\section{METHODS AND MATERIALS}

\section{ACUTE TOXICITY STUDIES}

Chloroform saturated water cannot be effectively prepared by simply stirring the two together due to the slow rate of solution, so a flow-through toxicant delivery system was constructed (Figure 1) that produced a continuous supply of stock solution saturated with chlorof on at $8000 \mathrm{ppm}$. A chloroform saturation column was developed to increase the water-chloroform contact. The saturation column is a $0.61 \mathrm{~m}$ glass column filled with $3 \mathrm{~mm}$ glass beads, with bands of glass wool at $15 \mathrm{~mm}$ intervals. A peristaltic pump with Viton tubing, which is resistant to the solvent properties of chlorof orm, metered chlor of orm into the saturation column at a flow rate of $\sim 1.0 \mathrm{~m} \ell / \mathrm{min}$. Deionized water was added to maintain a constant head in the column at an average flow rate of 90 $\mathrm{m} \ell / \mathrm{min}$. The solution flowed into a magnetically stirred $4-\ell$ amber-glass carboy; then into a second $4-\ell$ amber-glass carboy which was not stirred. This permitted settling of fine chloroform droplets from the saturated solution prior to pumping it to the toxicant manifold.

A stainless steel, positive displacement pump with a ceramic head was used to pump the chloroform-saturated water to the toxicant manifold. The saturated solution was metered into funnels in dilution cells where it mixed with Columbia River water prior to flowing to the aquaria. The toxicant delivery system was designed to minimize turbulent mixing and bubbling which could reduce the chloroform concentration in water. Variability of chloroform concentration with time in each aquarium was determined by daily chloroform measurement. Daily variations between samples from different aquaria were no larger than the variance between multiple samples from a single aquarium. Because of day-to-day variability, chlorof orm samples were collected twice during each bioassay, at the beginning and near the end of the 96-hr test. Chlorof orm samples were analyzed on a Hewlett Packard-5830 gas chromatograph with an $18^{\prime \prime}$ Porapak $Q$ column operated at $185^{\circ} \mathrm{C}$ and using a ${ }^{63} \mathrm{Ni}$ electron capture detector.

Water flow rates to each $50-\ell$ aquaria were equal during each test. At the beginning of a test, water flow in each aquarium was adjusted to a level ranging from 1.0 to $1.5 \mathrm{l} / \mathrm{min}$ depending on fish oxygen requirements and the ASTM recormended flow rate (Sprague, 1973). The diurnal light cycle was automatically controlled to a 12-hr light/dark cycle. Aerated Columbia River water was maintained at a constant temperature within $0.1^{\circ} \mathrm{C}$ during each test using a Research Incorporated Temperature Controller with an Esterline Angus PD2064 microprocessor to monitor and record the temperature each half hour. Acclimation and test temperatures used were near the middle of the tolerance range for each species to avoid combined stresses of temperature and toxicant. Fish were held in the test temperature and light regime at least two weeks prior to testing and were not fed for two days prior to the testing.

Bluegill, catfish and largemouth bass were purchased from the Osage Catfish Fishery in Osage Beach, Missouri. Rainbow trout were purchased from the Soap Lake Hatchery in Soap Lake, Washington. Each species was held for at least 
two months to insure that stocks were in good condition prior to testing. Fish were fed Silvercup fish food with the exception of largemouth bass which were fed live juvenile rainbow trout. In previous toxicity tests at our laboratory, and in tests by Mehrle et a1. (1977), this diet was shown to provide adequate nutritional requirements.

In order to minimize effects of fish growth on the test results, the complete series of toxicity tests for each species were completed before testing another species. This was not possible with bluegill, in which an outbreak of columnaris disease occurred during the series of tests. Testing was suspended for bluegill until the columnaris infection was controlled. Tests for other species were conducted during the interim. Length and weight measurements of the test fish were made following each test (Table 1).

The experimental design of the toxicity tests is in accordance with that recommended by Sprague (1973). Chloroform concentration sequence in the test system is random. The sequence of loading fish into the aquaria for each test is performed following a random numbers table. This randomization minimizes the possibility of the testing system arrangement and fish loading selectivity on the outcome of the toxicity test.

Statistical analyses of the toxicity test results were analyzed on a PDP 1170 computer. Stephan's (1977) program was used to compute the $L C_{50}$ s and 95\% confidence intervals. The program computes $L C_{50}$ s by probit, moving average and binonial computational procedures.

\section{BIOACCUMULATION STUDIES}

Fish used for the bioaccumulation studies were from the same stock purchased for use in the acute toxicity tests except for catfish. Juvenile catfish were required in the acute toxicity testing because fighting occurred when three or more adult fish were placed in the same aquarium. Both test stocks of catfish were obtained from the same vendor although the fish used in the bioaccumulation study were about one year older than those used in the acute toxicity tests. Size of the fish stocks is shown in Tables 2-5. The treatment and feeding of fish stocks is the same as discussed in the acute toxicity section. No disease or mortality of control fish was observed in any bioaccumulation studies.

The toxicant delivery system was modified to eliminate the contact column (Figure 1). This reduced the concentration of the stock solution permiting establishment of 1 to $2 \mathrm{ppm} \mathrm{CHCl}_{3}$ in the test aquaria. Flow rates through each 50- \& aquarium were 1 to 2 liters per minute depending on the tests. Tests were conducted in paired aquaria. The toxicant delivery system was operated at test levels for $24 \mathrm{hr}$ prior to start of the bioaccumulation tests so that chloroform levels could stabjlize. Concentrations of chloroform were measured 1 to $2 \mathrm{hr}$ prior to testing, at the time that the fish were added to the water and two to three times throughout the 24-hr testing period. 
During the depuration phase of the tests, fish were transferred en masse to an aquarium without chloroform and the water monitored at $15 \mathrm{~min}$ and $1 \mathrm{hr}$ to determine chloroform concentrations in the depuration tank. In all cases, $<0.01 \mathrm{ppm} \mathrm{CHCl}_{3}$ was found at $15 \mathrm{~min}$. No chloroform was detected after $1 \mathrm{hr}$. In the bluegili tests, samples of water for chloroform analysis were taken after $24 \mathrm{hr}$ of depuration. This further substantiated the rapid loss and low chloroform levels in the depuration aquaria. The light/dark diurnal period was regulated to $12 \mathrm{hr}$ of light and $12 \mathrm{hr}$ of darkness. Temperature was held constant at the acclimation temperature for each species. In all cases, filtered Columbia River water was used. Test temperature was controlled using a Research Incorporated Temperature Controller with an Esterline Angus PD2064 microprocessor to monitor and record the temperature for each half hour of the test.

At the beginning of each test the fish were transferred into test aquaria following a sequence from a random numbers table. The sequence of removal of fish at each sampling was also done randomly. Care was taken to minimize stress in handling when fish were added to the aquaria and during transfer to the depuration aquaria. At each sampling, fish were removed sequentialiy by a random sampling sequence, cudgeled to minimize activity; weighed, measured and placed on ice to await sectioning within the next few minutes. Sequence of sectioning was the same as removal from test aquaria. Single fish were sectioned vertically into $1 \mathrm{~cm}$ pieces and placed in glass jars and mascerated to facilitate chloroform extraction by methanol. Fish were covered with a known volume of methanol (Burdick and Jackson distilled in glass methanol). Extraction of chloroform occurred for 24 to $48 \mathrm{hr}$ prior to a second methanol extraction. During the methanol extractions, tissues were held at $4^{\circ} \mathrm{C}$ to minimize chloroform loss due to volatilization. Methanol extracts were measured and a 50-ml aliquot from each jar retained for further analysis. A third volume of methanol was replaced, covering the fish if further extraction was found to be necessary.

Chloroform concentrations in water and methanol extracts were determined by gas chromatography. One microliter samples of water, methanol or water diluted with methanol were injected directly onto an 18 inch Porapak $Q$ column gperated isothermally at $130^{\circ} \mathrm{C}$ and the chloroform content was measured with a $63 \mathrm{Ni}$ electron capture detector. Standards were run with each set of samples. The method is not linear over the entire calibration range, so sample values had to be calculated using standards of similar concentration. Analysis of spiked samples showed no bias in the method when aqueous samples were kept cold and tightly sealed to prevent loss of chloroform. The limit of detection of this method is approximately $5 \times 10^{-10} \mathrm{~g} \mathrm{CHCl}_{3} / \mathrm{m}$ \& water and the coefficient of variation has been estimated at $3 \%$ over the entire calibration range.

Preliminary studies were conducted with trout tissues in order to determine the number of methanol extractions required to remove chloroform from fish tissue. These preliminary studies indicated that $97.5 \%$ of the chloroform was removed during the first two chloroform extractions of fish tissue. 0nly in very few instances was any chloroform found in the third extraction. The samples were analyzed in a random order to minimize analytical bias. 
RESULTS

\section{ACUTE TOXICITY TESTS}

Test fish can be placed in two groups by sensitivity to chloroform. The first group, trout and bluegill, with 96-hr LC $C_{50}$ 's less than $25 \mathrm{ppm}$ chloroform and the second group, largemouth bass and catfish, with $L C_{50}$ 's greater than $25 \mathrm{ppm}$ (Tables 6-9). Mortality rate for bluegill and Yargemouth bass in response to toxic chloroform levels was high during the first day with little mortality occurring later in the test (Figures 2 and 3 ). Trout and catfish, (Figures 4 and 5), tended to exhibit an initial tolerance to chjoroform with mortality increasing later in the toxicity test except at chloroform levels well above the $L C_{50}$ where no tolerance was evident.

\section{Largemouth Bass}

Six 96-hr flow-through chloroform toxicity tests were conducted with largemouth bass. The $96-\mathrm{hr} L C_{50}$ 's for largemouth bass range from 45 to $56 \mathrm{ppm}$ chloroform (Table 6). Mortality rate during each test was very high during the first $12 \mathrm{hr}$ with no further mortalities occurring between 12-96 hr (Table 10, Figure 2). Highest mortality rate was recorded during the first $4 \mathrm{hr}$ where $90-100 \%$ of the mortalities during the $96-\mathrm{hr}$ test occurred.

Distinct behavioral differences were noted between largemouth bass exposed to toxic levels of chloroform and controls. Exposed fish exhibited color changes, and "head down" position while resting. Occasionally the fish in the "head down" posture would swim energetically and erratically colliding with the top and sides of the aquarium. The energetic swiming was intermittent and occasionally concomitant with a sudden noise in the room. The behavioral response may be described as an excessive startle response.

\section{Channel Catfish}

In the initial toxicity tests adult channel catfish (one to two years old), exhibited aggressive behavior with two or more fish per aquarium. Mortality of all but one dominant fish occurred as a result of aggression. Since the aggressive behavior was not apparent in the fish holding tank, water siphoned from the tank was used to supply test aquaria. Results of behavioral studies by Todd (1971) suggested that "conditioned" water from areas of high catfish densities may contain a compound promoting survival under crowded conditions by reducing aggressive behavior. Although Todd's work explained why we were not finding excessive aggressive behavior in the fish in the holding tank, transfer of the water to a test aquarium with three fish and no chloroform did not reduce aggressive behavior in the test aquarium.

Yearling channel catfish were used to replace adult catfish used in early toxicity tests. The adult catfish (1-2 years old) became so aggressive in the confinement of the test aquarium that the dominant fish killed the others in 
the aquarium. Studies in the literature suggested that juvenile catfish do not behave similarly (Roseboom and Richey, 1977). Because of the behavioral difference between juvenile and adult catfish, juvenile catfish were found to be excellent test fish for toxicity studies.

While awaiting arrival of the juvenile catfish, a toxicity test with one adult catfish per aquarium was conducted to estimate the range at which mortality occurred. No mortalities occurred in any aquarium up to the maximum concentration of $68 \mathrm{ppm} \mathrm{CHCl}_{3}$.

Five toxicity tests were conducted with juvenile catfish. Survival of adult catfish during initial toxicity testing with one fish per aquarium at high chloroform levels indicated the LC $_{50}$ was high. Mortality or lack of mortality during early testing (Table 11, Figure 3) provided little information to determine the range of the $L C_{50}$. Several tests were required to first determine the approximate $L_{50}$ range prior to testing with concentrations near the resultant $L_{50} 75 \mathrm{ppm}$.

Mortality resulting from chloroform exposure shows a threshold resulting in a high incidence of $100 \%$ mortality or $100 \%$ survival among experimental organisms over a narrow concentration range. Partial test group mortalities rarely occurred. These bioassay results are difficult to interpret with probit analysis, which requires several partial test group mortalities to maximize the accuracy of the $\mathrm{LC}_{50}$ and minimize the confidence intervals. Thus the binomial method and the moving average method were also used to compute 96-hr LC 50 s (Stephan, 1977).

\section{Rainbow Trout}

Acute toxicity tests with juvenile rainbow trout produced a range of $96-\mathrm{hr}$ $\mathrm{LC}_{50}$ s between 15-22 ppm $\mathrm{CHCl}_{3}$ with a mean of $18.2 \mathrm{ppm} \mathrm{CHCl}_{3}$ ( $\mathrm{Table} \mathrm{9}$ ). There appears to be a threshold effect of chloroform with rainbow trout as well as with bluegill. There was either nearly $100 \%$ mortality or $100 \%$ survival in concentrations differing less than 2-3 ppm during each toxicity test (Table 12, Figure 4).

There was an obvious behavioral difference between controls and fish in high chloroform concentrations. In concentrations of chloroform near $20 \mathrm{ppm}$ or greater, rainbow trout stratified near the surface exhibiting what we describe as "escape behavior". Fish swim with their noses out of the water. Fish stratification, evident during the day in the high chloroform levels, did not occur at night. Frequently a fish would swim quickly in random directions hitting the tank cover and walls. This intense activity was followed by loss of equilibrium. At levels greater than $13 \mathrm{ppm}$, fish were excitable and easily startled and sudden illumination of the aquaria at night caused fish to swim in an erratic manner. Fish in lesser concentrations of chloroform did not exhibit the same startle response and responded more slowly to the light stimulation. Exhibiting loss of equilibrium, slow opercular movement and apparently near death on the tank bottom, these fish often revived after a few minutes, although loss of equilibrium sometimes lasted for as long as an hour. Fish near death often exhibited stress marks or patches of dark and light coloring over their bodies. 
Bluegil1

In six acute toxicity tests of chloroform with bluegill the $96-\mathrm{hr} \mathrm{LC}_{50} \mathrm{~s}$ ranged from 13.3-22.3 ppin with a mean $L C_{50}$ of $18.2 \mathrm{ppm}$ (Table 8). The mortality rate was highest during the first $12 \mathrm{hr}$ with little further mortality occurring during the ensuing $84 \mathrm{hr}$ of the test (Table 13, Figure 5). Color changes exhibiting stress were evident prior to mortality in some fish. No other behavioral differences were evident between control and exposed fish.

A prophylactic effect of chloroform on columnaris disease (Flexibacter columnaris) was demonstrated during a toxicity test with bluegill. The stock of test fish exhibited no obvious signs of columnaris within the two weeks prior to the initiation of the $96-\mathrm{hr}$ toxicity test. During the second day of the test, the mortality rate in the control aquarium was extremely high, with complete mortality occurring within $48 \mathrm{hr}$. Each mortality was examined for evidence of columnaris disease. Columnaris was found in the control and in the two low chloroform concentrations of 12.0 and $13.6 \mathrm{ppm}$. In the two highest chloroform concentrations, 17.1 and $14.9 \mathrm{ppm}$, no mortalities occurred during the first three days when the test was teminated. Chloroform toxicity in earlier bioassays with bluegill occurred primarily during the third and fourth days. Thus, mortality early in the test and at relatively low chloroform concentrations can be attributed to columnaris infection of the gills in two test concentrations of 17.1 and $14.9 \mathrm{ppm}$. An exanination of the unexposed bluegill holding stock indicated a low-level columnaris infection. Apparently the stress of handling fish prior to the outset of the bioassay was sufficient to cause an outbreak of the disease. Chloroform concentrations greater than $14.9 \mathrm{ppm}$ were sufficient to inhibit or reduce the columnaris infection.

\section{BIOACCUMULATION STUDIES}

Rainbow Trout

Rainbow trout exhibited the highest bioaccumulation factor of any of the species tested (Table 2, Figure 6). Within $1 \mathrm{hr}$ of exposure, the tissue Jevel of chloroform in trout was $4 \mu \mathrm{g}$ of chloroform per gram of fish tissue. This is the approximate tissue level achieved in other test species at $4 \mathrm{hr}$ of exposure. Chloroform level in trout tissue then nearly doubled to $7 \mathrm{\mu g}$ per gram of tissue at $4 \mathrm{hr}$. At the $24 \mathrm{hr}$ sampling, the mean chloroform concentration of $5.5 \mu \mathrm{g} \mathrm{CHCl} / 3 / \mathrm{g}$ tissue, was lower than at $4 \mathrm{hr}$. Prel iminary tests were conducted with a much higher level of chloroform than the one per million level finaliy used to determine the period of exposure and depuration. They showed that chloroform levels did not increase from 4 to $8 \mathrm{hr}$. The $8-\mathrm{hr}$ sampling time was eliminated and replaced by a 24-hr sampling to provide time for an equilibrium between fish and water concentrations to occur. 
The mean chloroform concentration in rainbow trout decreased by $50 \%$ within 15 min of the start of depuration and within $4 \mathrm{hr}$, the levels were below $1 \mathrm{\mu g}$ $\mathrm{CHCl}_{3} / \mathrm{g}$ tissue. By $48 \mathrm{hr}$ the levels in the fish had decreased to below the level of detection. No behavioral changes were noted in the trout during exposure to $1.0 \mathrm{ppm} \mathrm{CHCl}_{3}$. The fish were evenly distributed throughout the aquaria during both accumulation and depuration phases of the test.

\section{Bluegill}

Bioaccumulations of chloroform in bluegill was similar to rainbow trout in that an initial high level of chloroform observed at $4 \mathrm{hr}$ decreased at $24 \mathrm{hr}$ (Table 3 and $\mathrm{Figure} \mathrm{7).} \mathrm{Although} \mathrm{the} \mathrm{maximum} \mathrm{level} \mathrm{of} \mathrm{CHCl}_{3}$ in bluegill is less than half that of rainbow trout, a detectable level of chloroform was extracted from bluegill tissue following a day of depuration (Figure 7).

\section{Largemouth Bass}

Accumulation of chloroform in largemouth bass differs from trout and bluegill in that tissue levels do not decrease after 4-hr (Table 4). The 4-hr and 24-hr exposures are similar. Rapid depuration is shown by the decrease in concentration to below detection limits within $4 \mathrm{hr}$ of removal from chloroform exposure (Figure 8). Sampling after 4-hr of depuration did not reveal a detectable level of chloroform in the tissues nor was there any following $24 \mathrm{hr}$ of depuration.

The bioaccumulation of chloroform in bass was about half that of trout and approximately equal to the tissue levels of bluegill and catfish.

\section{Channel Catfish}

Channel catfish did not exhibit the rapid bioaccumulation of chloroform as did the other fish species during the first $4 \mathrm{hr}$ of exposure (Figure 9). Peak concentration of chloroform occurred at $24 \mathrm{hr}$ (Table 5). These results differ from those on trout or bluegill in which concentrations at $24 \mathrm{hr}$ were less than at $4 \mathrm{hr}$. Concentrations of chloroform in catfish at $4 \mathrm{hr}$ were approximately equal to trout tissue levels at 15 min of exposure. Chloroform levels in catfish tissue at $24 \mathrm{hr}$ of exposure were approximately equal to levels in bass and bluegill at the same sampling time, and were about $2 / 3$ of the level found in trout tissue at $24 \mathrm{hr}$. Since the shape of the accumulation curve does not exhibit a plateau or decrease from a peak in tissue level of chloroform, and catfish show the slowest rate of accumulation in the species tested, the maximum tissue level of chloroform may not have been reached. Further studies should be conducted with catfish to determine at what exposure period the tissue concentration of chloroform begins to stabilize or decrease.

Depuration of chloroform was rapid, decreasing to less than $0.1 \mathrm{ppm} \mathrm{CHCl}_{3} / \mathrm{g}$ tissue following 24-hr depuration. The rapid depuration of chloroform from catfish was similar to that of trout and bass, but was more rapid than bluegill. 


\section{DISCUSSION}

Fish sensitivity to chloroform as indicated by $96-\mathrm{hr} \mathrm{LC}_{50} \mathrm{~s}$ ranges from 18 ppm for rainbow trout and bluegill to 51 and 75 ppm for largemouth bass and channel catfish, respectively. Although the $96-\mathrm{hr} \mathrm{LC}_{50} \mathrm{~s}$ provide an indication of the sensitivity of fish to chloroform, examination of the mortality rates during each toxicity test provides additional information. Mortality rates for bluegill and largemouth bass were high during the first day of exposure with little further mortality occurring later in the toxicity test. Trout and catfish, which had the lowest and highest $96-\mathrm{hr} \mathrm{LC}_{50} \mathrm{~s}$ respectively, demonstrated similar mortality patterns at test concentrations. They tended to exhibit an initial tolerance and low mortality with increasing mortality later in the toxicity test. Although with relatively high chloroform concentrations in regard to the $L_{50}$, mortality was high during the initial portion of the test.

In the four species tested, a threshold effect was evident. A high incidence of $100 \%$ mortality or $100 \%$ survival occurred over a narrow chloroform concentration range of 2 to $3 \mathrm{ppm} \mathrm{CHCl}_{3}$. Partial test-group mortality rarely occurred. Although chloroform is acutely toxic to fish from 18-75 ppm, depending on the species, this is orders of magnitude higher than the levels of chloroform expected to be produced during chlorination at power plants. Thus given the expected levels of chloroform production from chlorination, acute chloroform toxicjty to freshwater fish does not appear to be a problem.

A prophylactic effect of chloroform on columnaris disease was evident during a toxicity test with bluegill that was terminated. Although the stock of test fish exhibited no obvious signs of columnaris within two weeks prior to testing, the stress of handling apparently was sufficient to cause an outbreak of the disease. Chloroform concentrations of 15-17 ppm were found to be sufficient to inhibit or reduce the columnaris infection.

Chloroform was found to alter the behavior of rainbow trout and largemouth bass. Both species were observed to swim erratically and energetically during chloroform exposures. Intense activity was followed by a loss of equilibrium with slow opercular movement. Loss of equilibrium occurred for periods of a few minutes or as long as an hour. Although slow opercular movement was apparent prior to mortality, it is not clear if retardation of the respiratory process results in oxygen deprivation. Trout also exhibit a definite change in social structure or behavior in test aquaria at chloroform concentrations greater than $10 \mathrm{ppm}$. Trout stratify near the surface of test aquaria, whereas in the control aquarium fish are evenly distributed. There is an increased sensitivity to light or noise disturbances in fish exposed to chloroform. Sudden illumination of the room at night sends rainbow trout, bluegill and Targemouth bass into frenzied swiming activity for several minutes. This heightened startle-response was not noted in channel catfish.

of the four species of fish tested, rainbow trout accumulated the highest level of chloroform in the tissues, $7 \mu \mathrm{g} \mathrm{CHCl} / 3 / g$ tissue. Catfish accumulated the next highest tissue concentration at $4.3 \mu \mathrm{g} \mathrm{CHCl} / \mathrm{g}$ tissue, 
followed by bluegill and largemouth bass which accumulated approximately $3 \mu \mathrm{g}$ $\mathrm{CHCl}_{3} / \mathrm{g}$ tissue. In all species tested, the bioaccumulation of chloroform from the concentration in water was less than one order of magnitude. A11 species were exposed to levels of chloroform ranging from 1.0 to $1.5 \mathrm{ppm}$ $\mathrm{CHCl}_{3}$, which is equivalent to a tissue concentration of $1.0-1.5 \mu \mathrm{CHCl} / \mathrm{g}$ tissue with a concentration factor of one.

Those species which were most sensitive to chloroform during the acute toxicity tests, exhibited similar patterns of accumulation or depuration during the chloroform bioaccumulation studies. Trout and bluegill both had their highest. tissue levels of chloroform at $4 \mathrm{hr}$ of exposure with a reduced chloroform level at $24 \mathrm{hr}$ of exposure. Bass reached peak concentrations in about $4 \mathrm{hr}$. These were similar to the $24 \mathrm{hr}$ concentrations.

Catfish was the only species tested that had a substantial increase in tissue concentration of chlorof orm between the 4-hr and 24-hr sampling times. Due to the nature of this pattern, e.g., the lack of decrease or plateau in the accumulation pattern, the bioconcentration factor cannot be determined. Catfish was the most tolerant to chloroform of species tested with 96-hr $\mathrm{LC}_{50}$ of $75 \mathrm{ppm} \mathrm{CHCl}_{3}$. Also the pattern of mortality during the toxicity tests indicated an initial tolerance to chloroform levels near the $\mathrm{LC}_{50}$ with mortality increasing during the latter half of the toxicity tests. Trout also followed this pattern of an initial tolerance to chloroform levels, although the pattern of bioaccumulation of chloroform was substantially different than that of catfish.

The ability of fish to accumulate chloroform rapidly is shown in trout's accumulation of $3 \mu \mathrm{g} \mathrm{CHCl} 3 / g$ tissue in one hour and $7 \mu \mathrm{CHCl}_{3} / \mathrm{g}$ tissue at $4 \mathrm{hr}$ of exposure to $1 \mathrm{ppm} \mathrm{CHCl}_{3}$. Rapid depuration rates also occurred. Although power plants using fresh water normally chlorinate intermittently rather than continuously, the chloroform produced may be accumulated during the short-term exposures. Chlorof orm concentrations can be expected to be highest in tissues with high lipid content such as developing gonads and fish eggs due to chioroform solubility in lipid. 


\section{CONCLUSIONS AND RECOMMENDATIONS}

- The 96-hr LC $C_{50} \mathrm{~s}$ were $18.2 \mathrm{ppm}$ for rainbow trout and bluegil1, $51.2 \mathrm{ppm}$ for 1 argemouth bass and 75 ppm for channel catfish.

- Although ch1oroform was observed to be lethal to these fish, lethal levels are several orders of magnitude above that expected to be produced under normal power plant operating conditions.

- Observed changes in fish behavior also occurred at chloroform threshold levels above that expected to be discharged from power plants.

- Chloroform accumulated in fish tissues at three to seven times the water concentration during exposures of up to $4 \mathrm{hr}$.

- Rapid depuration of tissue chloroform levels was observed in most species.

- Although most power plants sited on freshwater normally chlorinate intermittently, accumulation of chloroform in fish tissues can be expected during these short term exposures.

- Future research should examine the long term effects of repeated accumulation and depuration of chloroform that fish may experience as a result of power plant chlorination.

- Given the lipophilic nature of chloroform and the high Tipid content of fish eggs relatively high chloroform concentrations may occur in the developing gonads of female fish. The implications of this to fish reproduction are unknown.

- Studies of the combined effects of chlorine and chlorination by-products should be conducted since these will occur simultaneously in power plant discharges and the demonstrated affects of chlorine on membrane permeability may exacerbate the effects of chlorination by-products.

- Studies are also recommended in the long term effects of chloroform on reproduction, carcinogenicity, teratogenicity and mutagenicity in freshwater biota. 


\section{REFERENCES}

Mehrle, P. M., F. L. Mayer, and W. W. Johnson. 1977. Diet quality in fish toxicology: effects on acute and chronic toxicity. In: Aquatic Toxicology and Hazard Evaluation; ASTM STP 634, F. L. Mayer and J. L. Hamelink, Ed., American Society for Testing and Materials, pp. 269-280.

Roseboom, D. P., and D. L. Richey. 1977. Acute Toxicity of Residual Chlorine on Bluegill and Channel Catfish in I1linois. Trans. I1l. State Acade. Sci. $69(4): 385-398$.

Sprague, J. B. 1973. The ABC's of pollutant bioassay using fish. In: Biological Methods for the Assessment of Water Quality, ASTM STP 528, Anerican Soc iety for Testing and Materials, pp. 6-30.

Stephan, C. E. 1977. Methods for Calculating an LC50. In: Aquatic Toxicology and Hazard Evaluation, ASTM STP 634, F. L. Mayer and J. L. Hamelink, Ed., American Society for Testing and Materials, pp. 65-84.

Todd, J. H. 1971. The Chemical Language of Fishes. Scientific Anerican. Vol. 225. pp. 99-104. 


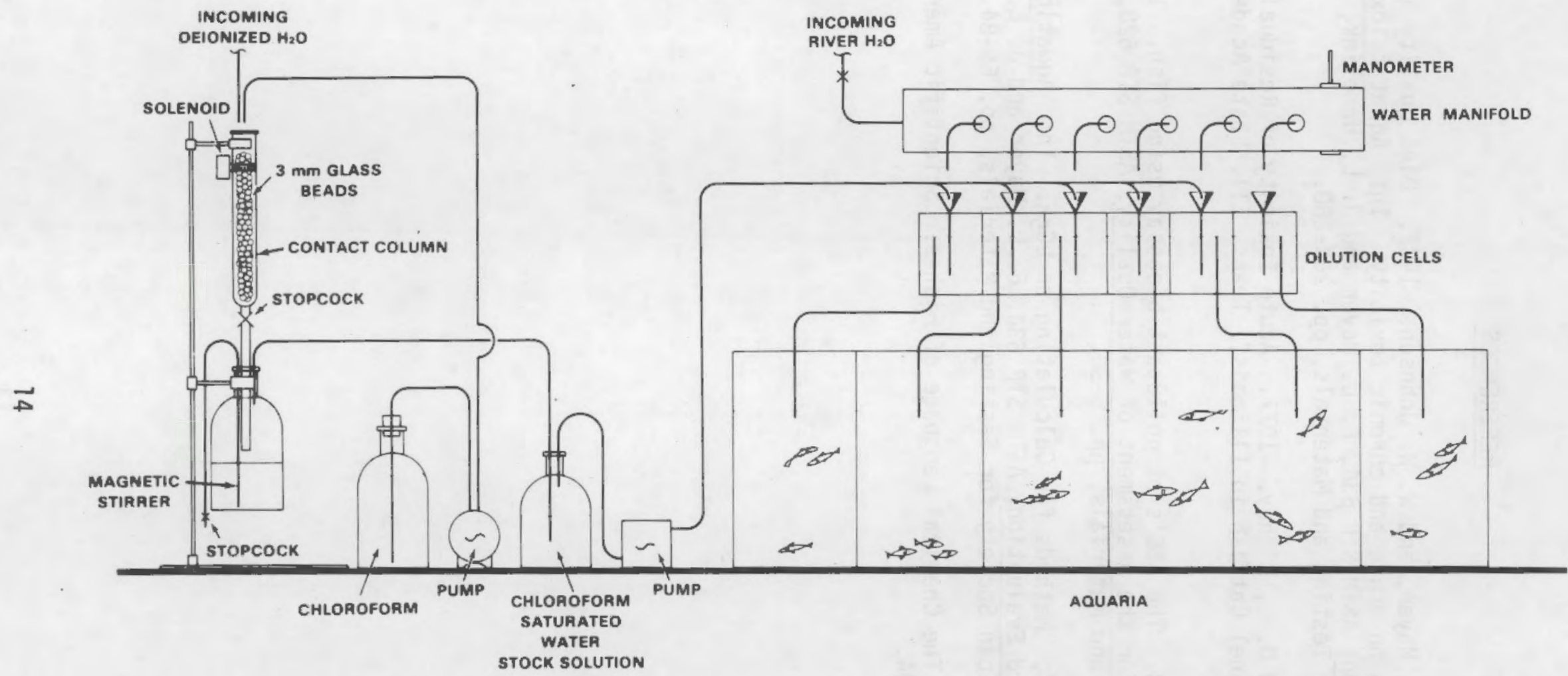

FIGURE 1. Delivery System Used for Acute Chloroform Tests of Freshwater Species. 


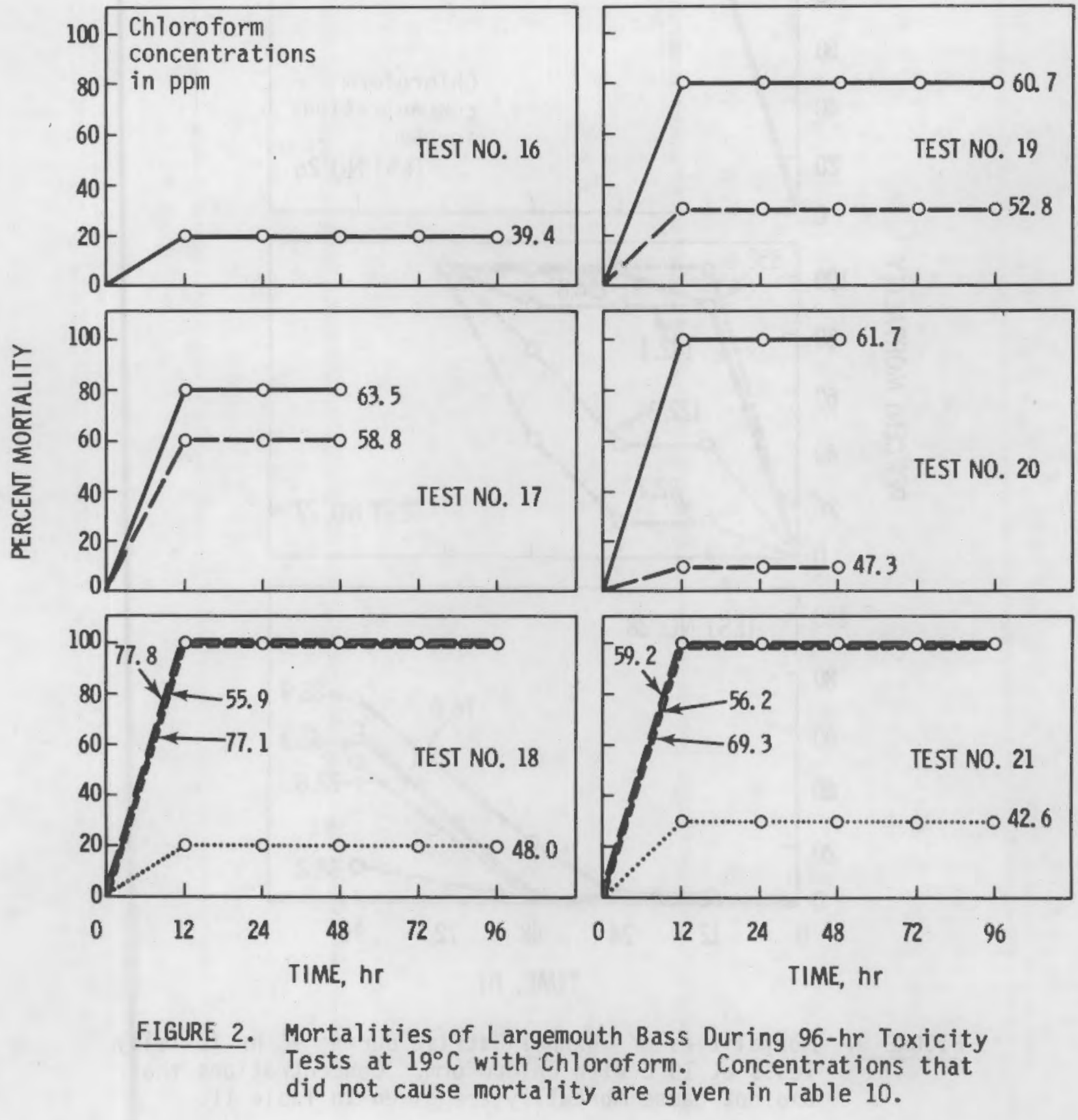



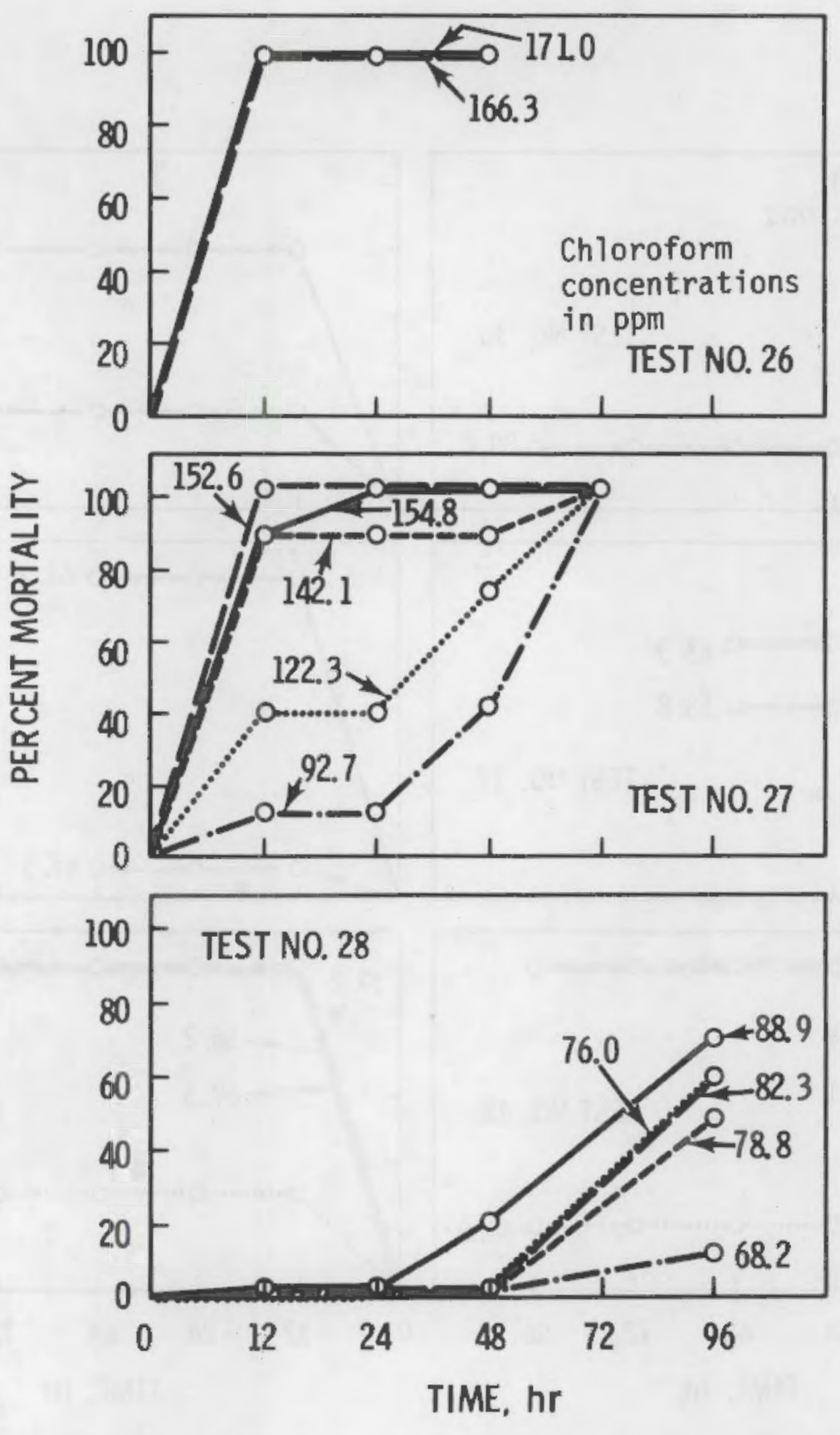

FIGURE 3. Mortalities of Channel Catfish During 96-hr Toxicity Tests at $19^{\circ} \mathrm{C}$ with Chloroform. Concentrations that did not cause mortality are given in Table 11. 


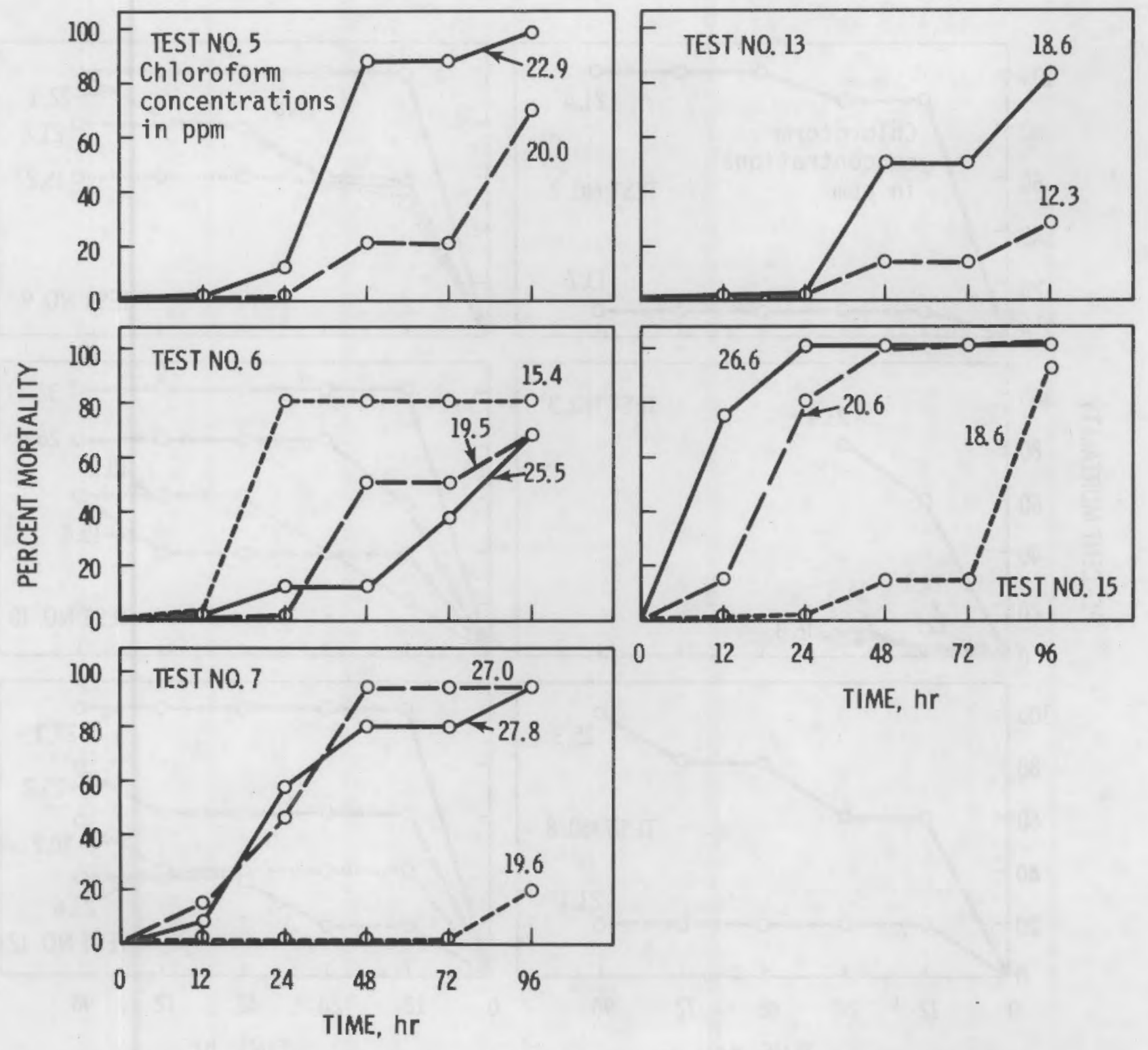

FIGURE 4. Mortalities of Rainbow Trout During 96-hr Toxicity Tests at $19^{\circ} \mathrm{C}$ with $\mathrm{Chl}$ oroform. Concentrations that did not cause mortality are given in Table 12 . 

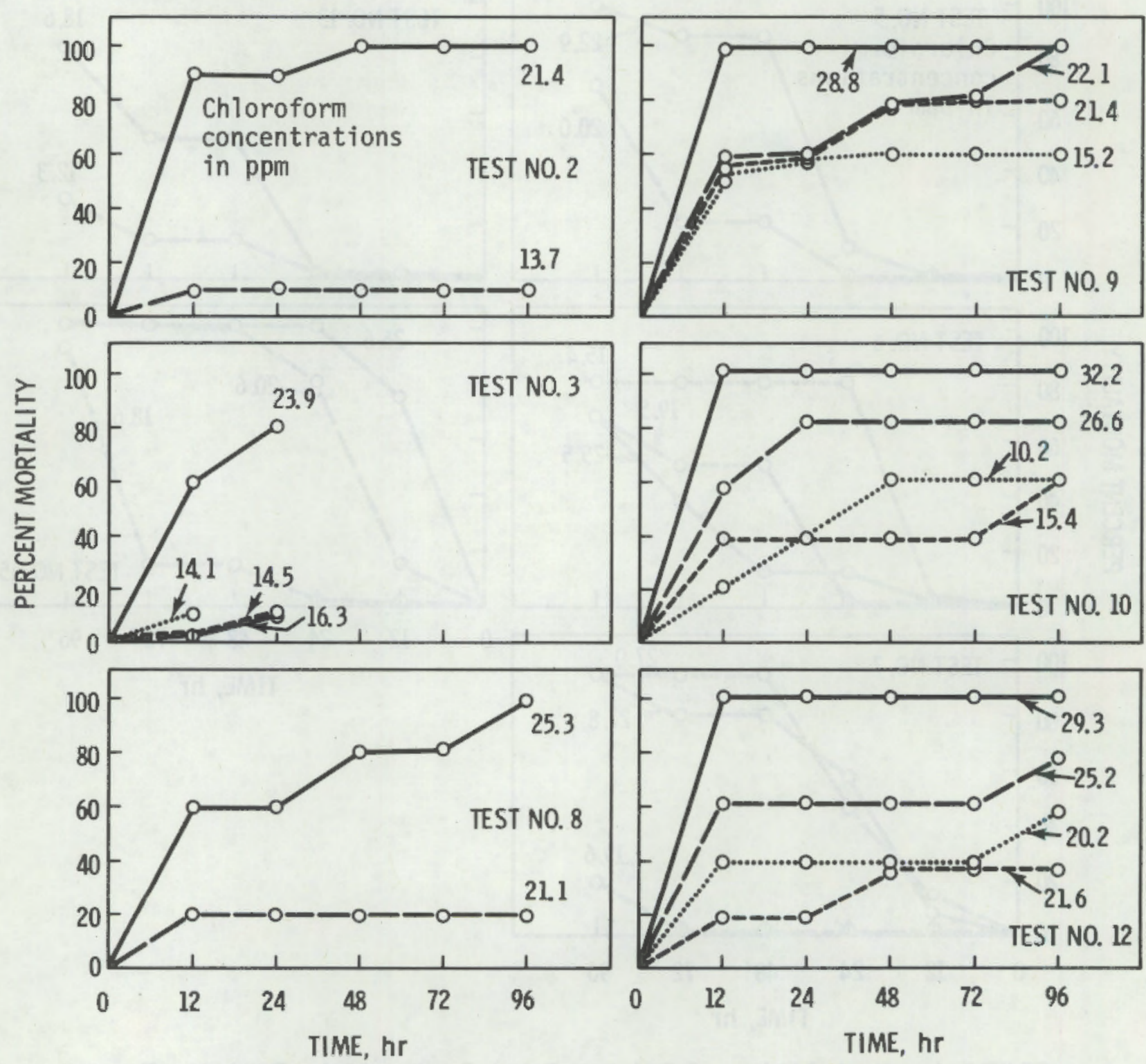

FIGURE 5. Mortalities of Bluegill During 96-hr Toxicity Tests at $19^{\circ} \mathrm{C}$ with Chloroform. Concentrations that did not cause mortality are given in Table 13 . 


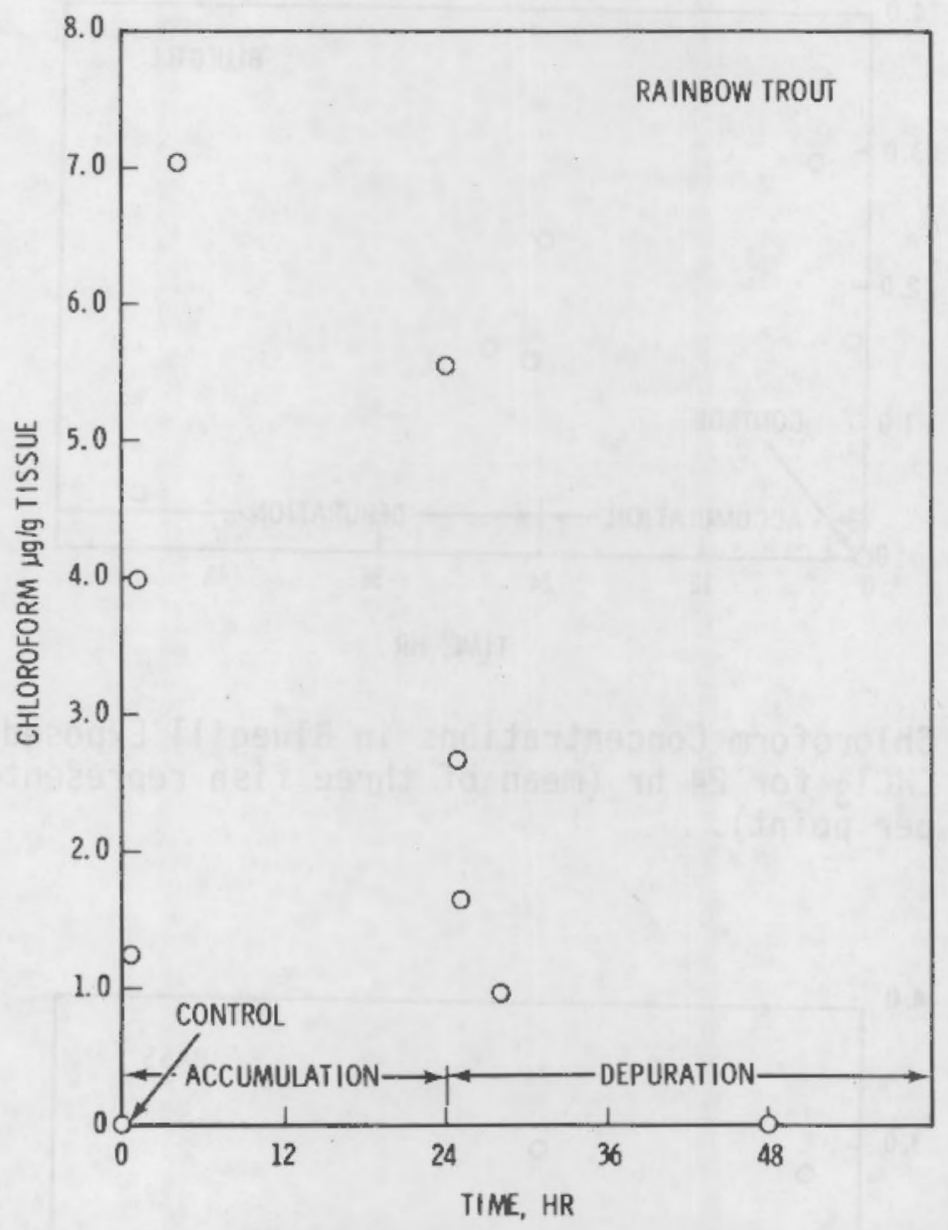

FIGURE 6. Chloroform Concentrations in Rainbow Trout Exposed to $1.0 \mathrm{ppm} \mathrm{CHCl}_{3}$ for $24 \mathrm{hr}$ (mean of two fish represented per point). 


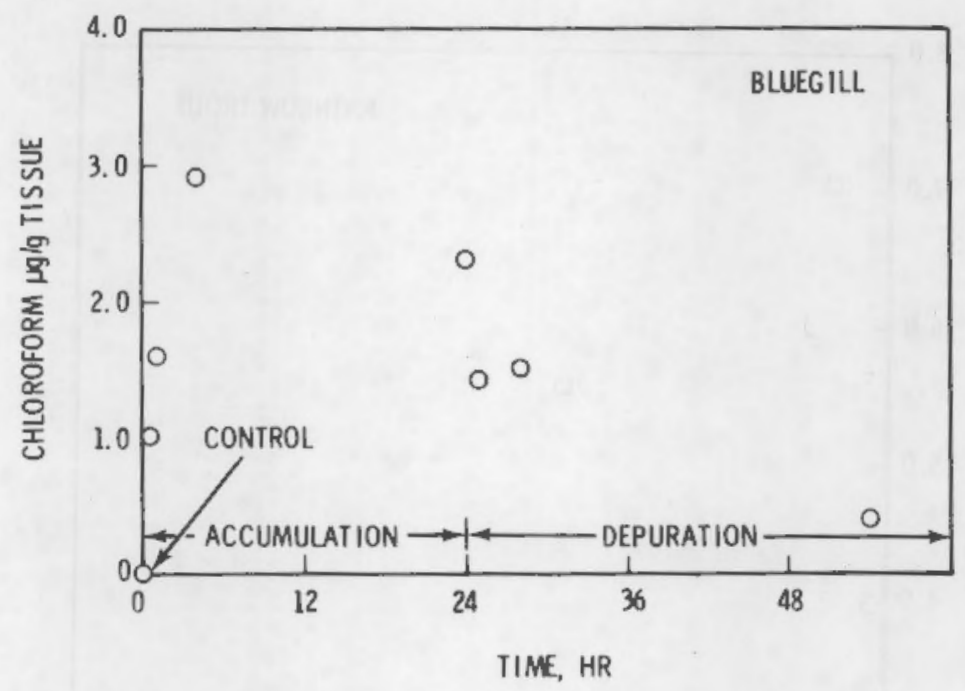

FIGURE 7. Chloroform Concentrations in Bluegill Exposed to $1.0 \mathrm{ppm}$ $\mathrm{CHCl}_{3}$ for $24 \mathrm{hr}$ (mean of three fish represented per point).

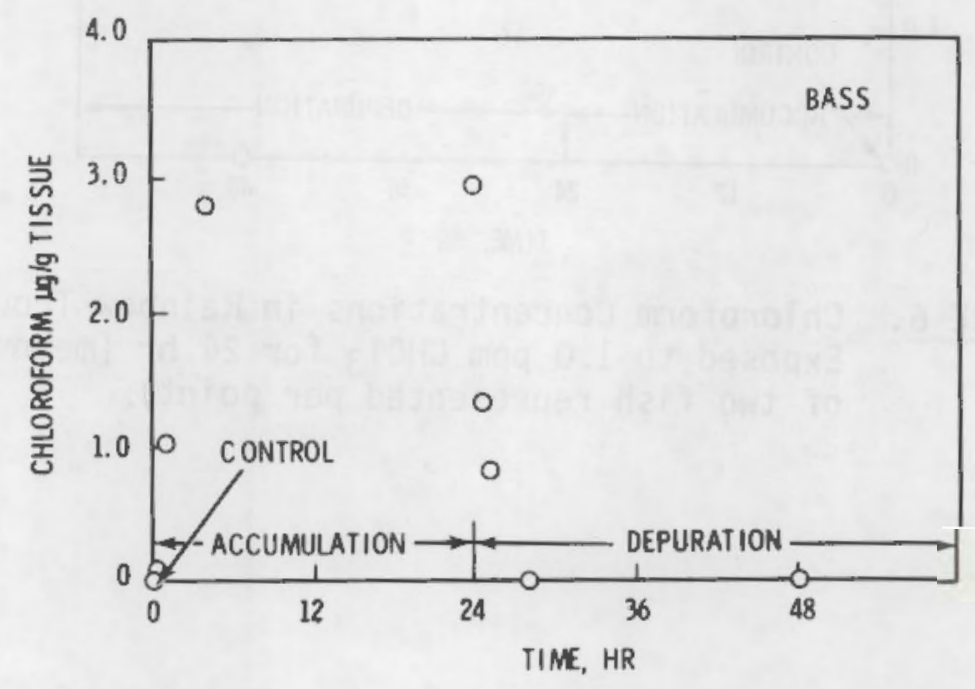

FIGURE 8. Chloroform Concentrations in Largemouth Bass Exposed to $1.0 \mathrm{ppm} \mathrm{CHCl} l_{3}$ for $24 \mathrm{hr}$ (mean of three fish represented per point). 


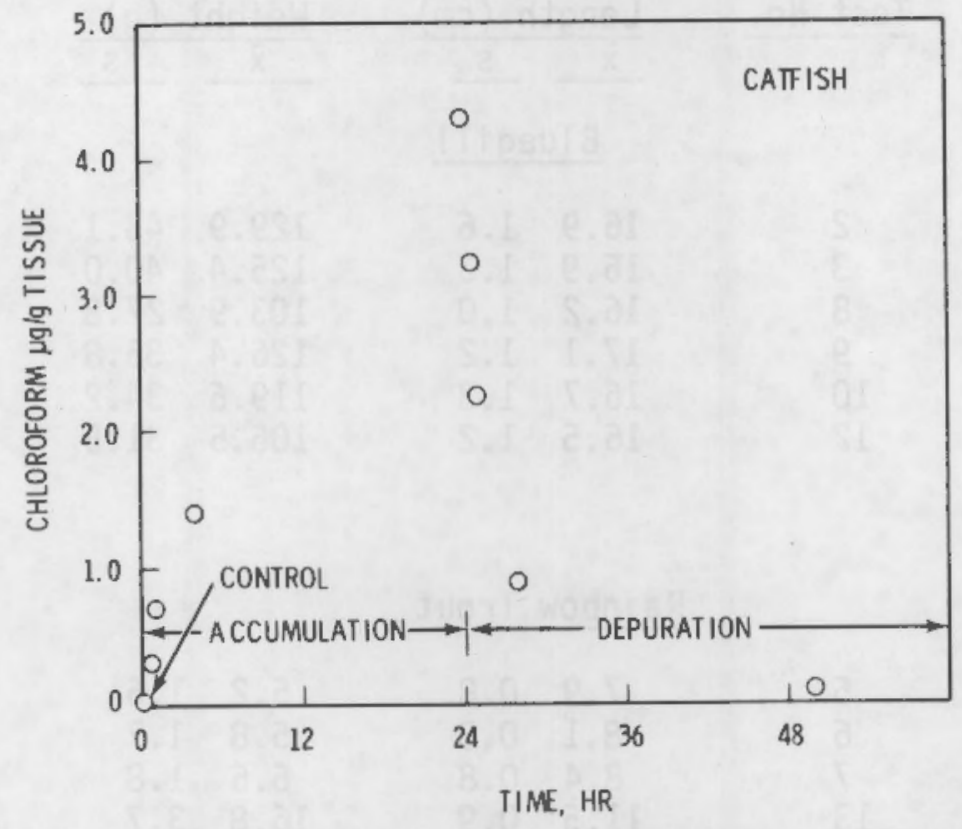

FIGURE 9. Chloroform Concentrations in Channel Catfish Exposed to $1.0 \mathrm{ppm} \mathrm{CHCl}_{3}$ for $24 \mathrm{hr}$ (mean of three fish represented per point). 
IABLE 1. Mean and Standard Deviation for Length and Weight of Fish Used in 96- $\mathrm{Hr}$ Chloroform

Toxicity Tests.

Test No. Length $(\mathrm{cm}) \quad$ Weight $(\mathrm{g})$

B] uegill

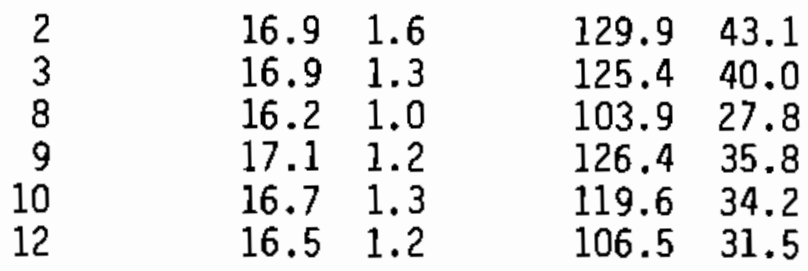

Rainbow Trout

$\begin{array}{rrrrr}5 & 7.9 & 0.8 & 5.2 & 1.6 \\ 6 & 8.1 & 0.8 & 5.8 & 1.7 \\ 7 & 8.4 & 0.8 & 6.6 & 1.8 \\ 13 & 11.5 & 0.9 & 16.8 & 3.7 \\ 15 & 8.8 & 1.0 & 7.6 & 2.2\end{array}$

Channel Catfish

$\begin{array}{lrlrr}11 & 23.6 & 1.4 & 152.5 & 28.2 \\ 22 & 26.4 & 2.1 & 239.2 & 68.1 \\ 25 & 11.9 & 1.5 & 16.8 & 7.6 \\ 26 & 12.0 & 1.2 & 20.3 & 8.0 \\ 27 & 11.9 & 1.8 & 21.6 & 9.8 \\ 28 & 12.1 & 1.5 & 21.4 & 9.2\end{array}$

\section{Largemouth Bass}

$\begin{array}{lrrrr}16 & 16.0 & 1.2 & 62.8 & 18.8 \\ 17 & 16.1 & 1.2 & 63.8 & 20.0 \\ 18 & 13.0 & 0.8 & 30.5 & 5.8 \\ 19 & 12.9 & 0.8 & 27.9 & 5.0 \\ 20 & 12.7 & 1.0 & 26.3 & 7.3 \\ 21 & 13.1 & 1.1 & 30.9 & 8.5\end{array}$


TABLE 2. Chloroform Accumulation/Depuration in Rainbow Trout During a 24-hr Exposure to 1.D ppm $\mathrm{CHCl}_{3}$ Followed by $24 \mathrm{hr}$ of Depuration at $20.2^{\circ} \mathrm{C}$.

\begin{tabular}{|c|c|c|c|}
\hline $\begin{array}{l}\text { Samp ling } \\
\text { time (hr) }\end{array}$ & $\begin{array}{l}\text { Fish } \\
\text { length }(\mathrm{cm})\end{array}$ & $\begin{array}{c}\text { Fish } \\
\text { weight }(g)^{a}\end{array}$ & $\begin{array}{l}\mathrm{CHCT}_{3} \\
\mu \mathrm{g} / \mathrm{g} \\
\text { tissue }\end{array}$ \\
\hline \multicolumn{4}{|c|}{ Exposure } \\
\hline $\begin{array}{l}0 \\
0\end{array}$ & $\begin{array}{l}14.9 \\
16.0\end{array}$ & $\begin{array}{l}38.1 \\
45.4\end{array}$ & $\begin{array}{l}0 \\
0\end{array}$ \\
\hline $\begin{array}{l}0.25 \\
0.25\end{array}$ & $\begin{array}{l}13.5 \\
16.3\end{array}$ & $\begin{array}{l}28.1 \\
50.8\end{array}$ & $\begin{array}{l}0.7 \\
1.10\end{array}$ \\
\hline 1 & $\begin{array}{l}12.8 \\
15.1\end{array}$ & $\begin{array}{l}25.8 \\
44.3\end{array}$ & $\begin{array}{l}4.0 \\
4.90\end{array}$ \\
\hline $\begin{array}{l}4 \\
4\end{array}$ & $\begin{array}{l}14.1 \\
14.5\end{array}$ & $\begin{array}{l}36.5 \\
39.4\end{array}$ & $\begin{array}{r}6.6 \\
10.2\end{array}$ \\
\hline $\begin{array}{l}24 \\
24\end{array}$ & $\begin{array}{l}12.7 \\
14.4\end{array}$ & $\begin{array}{l}22.7 \\
39.3\end{array}$ & $\begin{array}{r}3.34 \\
10.35\end{array}$ \\
\hline \multicolumn{4}{|c|}{ Depuration } \\
\hline $\begin{array}{l}24.25 \\
24.25\end{array}$ & $\begin{array}{l}13.0 \\
15.0\end{array}$ & $\begin{array}{l}26.4 \\
39.6\end{array}$ & $\begin{array}{l}3.3 \\
3.31\end{array}$ \\
\hline $\begin{array}{l}25 \\
25\end{array}$ & $\begin{array}{l}14.2 \\
16.0\end{array}$ & $\begin{array}{l}35.0 \\
48.7\end{array}$ & $\begin{array}{l}1.7 \\
2.4\end{array}$ \\
\hline $\begin{array}{l}28 \\
28\end{array}$ & $\begin{array}{l}14.4 \\
15.8\end{array}$ & $\begin{array}{l}33.6 \\
49.7\end{array}$ & $\begin{array}{l}1.1 \\
1.2\end{array}$ \\
\hline $\begin{array}{l}48 \\
48\end{array}$ & $\begin{array}{l}13.6 \\
16.3\end{array}$ & $\begin{array}{l}30.0 \\
48.2\end{array}$ & $\begin{array}{l}0.0 \\
0.0\end{array}$ \\
\hline
\end{tabular}

$\overline{\text { a Fish weight }}$ is based on live wet weight at sampling time. 
TABLE 3. ChToroform Accumulation/Depuration in Bluegill During a 24-hr Exposure to $1.0 \mathrm{ppm} \mathrm{CHCl}_{3}$ Followed by $3.0 \mathrm{hr}$ of Depuration at $26.3^{\circ} \mathrm{C}$.

\begin{tabular}{|c|c|c|c|}
\hline $\begin{array}{l}\text { Sampling } \\
\text { time (hr) }\end{array}$ & $\begin{array}{c}\text { Fish } \\
\text { length }(\mathrm{cm})\end{array}$ & $\begin{array}{c}\text { Fish } \\
\text { weight }(g)^{a}\end{array}$ & $\begin{array}{l}\mathrm{CHCl} \\
\mathrm{\mu g} / \mathrm{g} \\
\text { tiss }\end{array}$ \\
\hline \multicolumn{4}{|c|}{ Exposure } \\
\hline $\begin{array}{l}0 \\
0\end{array}$ & $\begin{array}{l}18.0 \\
19.5\end{array}$ & $\begin{array}{l}140 \\
221\end{array}$ & $\begin{array}{l}0 \\
0\end{array}$ \\
\hline $\begin{array}{l}0.25 \\
0.25\end{array}$ & $\begin{array}{l}16.3 \\
16.7\end{array}$ & $\begin{array}{r}90 \\
121\end{array}$ & $\begin{array}{l}1.3 \\
0.9\end{array}$ \\
\hline $\begin{array}{l}1 \\
1\end{array}$ & $\begin{array}{l}15.0 \\
18.1\end{array}$ & $\begin{array}{r}81 \\
166\end{array}$ & $\begin{array}{l}1.9 \\
1.6\end{array}$ \\
\hline $\begin{array}{l}4 \\
4\end{array}$ & $\begin{array}{l}17.4 \\
19.5\end{array}$ & $\begin{array}{l}149 \\
243\end{array}$ & $\begin{array}{l}3.0 \\
3.1\end{array}$ \\
\hline $\begin{array}{l}24 \\
24\end{array}$ & $\begin{array}{l}15.5 \\
17.4\end{array}$ & $\begin{array}{r}73 \\
130\end{array}$ & $\begin{array}{l}1.6 \\
2.5\end{array}$ \\
\hline
\end{tabular}

Depuration

$\begin{array}{lrrl}24.25 & 20.4 & 227 & b \\ 24.25 & 18.5 & 142 & b \\ 25 & 14.6 & 61 & 1.2 \\ 25 & 15.6 & 83 & 1.9 \\ 28 & 17.3 & 115 & 1.6 \\ 28 & 17.1 & 121 & 1.7 \\ 54 & 16.9 & 106 & 0.0 \\ 54 & 19.2 & 182 & 0.0\end{array}$

a Fish weight is based on live wet weight at sampling time.

b Samples contaminated during analysis. 
TABLE 4. Chloroform Accumulation/Depuration in Largemouth Bass

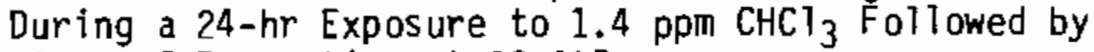
$24 \mathrm{hr}$ of Depuration at $23.4^{\circ} \mathrm{C}$.

\begin{tabular}{|c|c|c|c|}
\hline $\begin{array}{l}\text { Sampling } \\
\text { time (hr) }\end{array}$ & $\begin{array}{c}\text { Fish } \\
\text { length }(\mathrm{cm}) \\
\end{array}$ & $\begin{array}{c}\text { Fish } \\
\text { weight }(g)^{a}\end{array}$ & $\begin{array}{l}\mathrm{CHCl}_{3} \\
\mu \mathrm{g} / \mathrm{g} \\
\text { tissue } \\
\end{array}$ \\
\hline \multicolumn{4}{|c|}{ Accumulation } \\
\hline $\begin{array}{l}0 \\
0\end{array}$ & $\begin{array}{l}18.0 \\
14.3\end{array}$ & $\begin{array}{l}83.0 \\
35.4\end{array}$ & $\begin{array}{l}0 \\
0\end{array}$ \\
\hline $\begin{array}{l}0.25 \\
0.25\end{array}$ & $\begin{array}{l}16.0 \\
15.1\end{array}$ & $\begin{array}{l}46.1 \\
62.7\end{array}$ & $\begin{array}{l}0 \\
0\end{array}$ \\
\hline $\begin{array}{l}1 \\
1\end{array}$ & $\begin{array}{l}13.2 \\
16.4\end{array}$ & $\begin{array}{l}36.1 \\
47.5\end{array}$ & $\begin{array}{l}2.0 \\
0.1\end{array}$ \\
\hline $\begin{array}{l}4 \\
4\end{array}$ & $\begin{array}{l}15.9 \\
14.4\end{array}$ & $\begin{array}{l}49.5 \\
38.0\end{array}$ & $\begin{array}{l}2.2 \\
3.0\end{array}$ \\
\hline $\begin{array}{l}24 \\
24\end{array}$ & $\begin{array}{l}24.6 \\
14.6\end{array}$ & $\begin{array}{l}40.0 \\
42.4\end{array}$ & $\begin{array}{l}3.1 \\
2.9\end{array}$ \\
\hline \multicolumn{4}{|c|}{ Depuration } \\
\hline $\begin{array}{l}24.25 \\
24.25\end{array}$ & $\begin{array}{l}15.9 \\
13.6\end{array}$ & $\begin{array}{l}41.1 \\
27.2\end{array}$ & $\begin{array}{l}0.1 \\
1.4\end{array}$ \\
\hline $\begin{array}{l}25 \\
25\end{array}$ & $\begin{array}{l}16.1 \\
13.6\end{array}$ & $\begin{array}{l}67.4 \\
28.5\end{array}$ & $\begin{array}{l}2.5 \\
0.0\end{array}$ \\
\hline $\begin{array}{l}28 \\
28\end{array}$ & $\begin{array}{l}13.5 \\
13.2\end{array}$ & $\begin{array}{l}32.9 \\
21.9\end{array}$ & $\begin{array}{l}0.0 \\
0.0\end{array}$ \\
\hline $\begin{array}{l}48 \\
48\end{array}$ & $\begin{array}{l}14.6 \\
16.0\end{array}$ & $\begin{array}{l}39.6 \\
54.9\end{array}$ & $\begin{array}{l}0.0 \\
0.0\end{array}$ \\
\hline
\end{tabular}

a Fish weight is based on live wet weight at sampling time. 
TABLE 5. Chloroform AccumuTation/Depuration in Catfish During a 24-hr Exposure to $1.1 \mathrm{ppm} \mathrm{CHCl}_{3} \mathrm{~F}_{0} 1$ lowed by $26 \mathrm{hr}$ of Depuration at $24.3^{\circ} \mathrm{C}$.

\begin{tabular}{|c|c|c|c|}
\hline $\begin{array}{l}\text { Sampling } \\
\text { time (hr) }\end{array}$ & $\begin{array}{c}\text { Fish } \\
\text { length }(\mathrm{cm})\end{array}$ & $\begin{array}{l}\text { Fish } \\
\text { weight }(g)^{a}\end{array}$ & $\begin{array}{l}\mathrm{CHCl}_{3} \\
\mu \mathrm{g} / \mathrm{g} \\
\text { tissue }\end{array}$ \\
\hline \multicolumn{4}{|c|}{ Accumulation } \\
\hline $\begin{array}{l}0 \\
0\end{array}$ & $\begin{array}{l}38.4 \\
39.0\end{array}$ & $\begin{array}{l}588 \\
698\end{array}$ & $\begin{array}{l}0 \\
0\end{array}$ \\
\hline $\begin{array}{l}0.25 \\
0.25\end{array}$ & $\begin{array}{l}33.5 \\
36.4\end{array}$ & $\begin{array}{l}409 \\
528\end{array}$ & $\begin{array}{l}0.3 \\
0.3\end{array}$ \\
\hline $\begin{array}{l}1 \\
1\end{array}$ & $\begin{array}{l}39.6 \\
37.7\end{array}$ & $\begin{array}{l}640 \\
641\end{array}$ & $\begin{array}{l}0.5 \\
0.8\end{array}$ \\
\hline $\begin{array}{l}4 \\
4\end{array}$ & $\begin{array}{l}42.0 \\
38.5\end{array}$ & $\begin{array}{l}750 \\
630\end{array}$ & $\begin{array}{l}0.7 \\
1.5\end{array}$ \\
\hline $\begin{array}{l}24 \\
24\end{array}$ & $\begin{array}{l}37.2 \\
33.1\end{array}$ & $\begin{array}{l}562 \\
422\end{array}$ & $\begin{array}{l}3.3 \\
3.7\end{array}$ \\
\hline \multicolumn{4}{|c|}{ Depuration } \\
\hline $\begin{array}{l}24.25 \\
24.25\end{array}$ & $\begin{array}{l}38.4 \\
36.7\end{array}$ & $\begin{array}{l}641 \\
517\end{array}$ & $\begin{array}{l}2.8 \\
2.7\end{array}$ \\
\hline $\begin{array}{l}25 \\
25\end{array}$ & $\begin{array}{l}35.4 \\
40.2\end{array}$ & $\begin{array}{l}482 \\
660\end{array}$ & $\begin{array}{l}1.7 \\
1.1\end{array}$ \\
\hline $\begin{array}{l}28 \\
28\end{array}$ & $\begin{array}{l}39.3 \\
38.3\end{array}$ & $\begin{array}{l}689 \\
610\end{array}$ & $\begin{array}{l}1.3 \\
0.4\end{array}$ \\
\hline 50 & 33.5 & 371 & 0.23 \\
\hline
\end{tabular}

a Fish weight is based on live wet weight at sampling time. 
TABLE 6. Acute Chloroform $L_{50} \mathrm{~s}$ (ppm) With Largemouth Bass at $19^{\circ} \mathrm{C}$ in Columbia River Water.

$\begin{array}{lcccc}\text { Census Times } & 12 \mathrm{hr} & 24 \mathrm{hr} & 48 \mathrm{hr} & 96 \mathrm{hr} \\ \begin{array}{l}\text { Toxicity } \\ \text { Test No. }\end{array} & & & & \\ & & & & \\ 16 & & & & \\ 17 & 56.2 & 56.2 & \mathrm{~b} & \mathrm{a} \\ 18 & 50.4 & 50.4 & 50.4 & \mathrm{~b} \\ 19 & 55.8 & 55.8 & 55.8 & \mathrm{C} \\ 20 & 52.5 & 52.5 & 52.5 & 52.5 \\ 21 & 45.4 & 45.4 & 45.4 & 45.4\end{array}$

a No mortalities occurred in all test groups.

b Only one mortality occurred, insufficient data for $\mathrm{LC}_{50}$ calculation.

c Test terminated prior to the $48-\mathrm{hr}$ census time.

TABLE 7. Acute Chloroform $\mathrm{LC}_{50} \mathrm{~S}$ (ppm) With Channel Catfish at $19^{\circ} \mathrm{C}$ in Columbia River Water.

Census Times

$12 \mathrm{hr}$

$24 \mathrm{hr}$

$48 \mathrm{hr}$

$96 \mathrm{hr}$

Toxicity

Test No.

11

22

25

26

27

28

$\begin{array}{cc}a & a \\ a & a \\ a & a \\ 135^{c} & 135^{c} \\ 126^{d} & 126^{d} \\ a & a\end{array}$

$\begin{array}{cc}b & b \\ a & a \\ a & a \\ b & b \\ 101^{e} & b \\ a & 75^{d}\end{array}$

a Insufficient mortality to compute an $L_{50}$.

$b$ Test terminated.

c Binomial method.

d Moving average method.

e Probit method. 
TABLE 8. Acute ChToroform $\mathrm{LC}_{50} \mathrm{~s}$ (ppm) with Bluegill at $25^{\circ} \mathrm{C}$ in Columbia River Water.

$\begin{array}{llllc}\text { Census Times } & 12 \mathrm{hr} & 24 \mathrm{hr} & 48 \mathrm{hr} & 96 \mathrm{hr} \\ \begin{array}{l}\text { Toxicity } \\ \text { Test No. }\end{array} & & & & \\ \text { Ten } & & & & \\ 2 & 17.1 & 17.1 & 16.3 & 16.2 \\ 3 & 23.9 & 21.8 & \mathrm{a} & \mathrm{a} \\ 8 & 24.2 & 24.2 & 23.1 & 22.3 \\ 9 & 16.2 & 16.2 & 14.6 & 13.3 \\ 10 & 24.4 & 20.2 & 19.4 & 18.3 \\ 12 & 24.1 & 24.1 & 22.3 & 20.8\end{array}$

a Test terminated prior to 48 -hr census time due to disease mortality in the control aquarjum.

TABLE 9. Acute Chloroform $L_{50} S$ (ppm) With Rainbow Trout at $13^{\circ} \mathrm{C}$ in Columbia River Water.

Census Times

$12 \mathrm{hr}$

$24 \mathrm{hr}$

$48 \mathrm{hr}$

$96 \mathrm{hr}$

Toxicjty

Text No.

$\begin{array}{rcccc}5 & - & - & 21.4 & 18.2 \\ 6 & - & - & - & 18.4 \\ 7 & 37.1 & 26.1 & 23.6 & 22.1 \\ 13 & - & - & 18.6 & 15.1 \\ 15 & 24.5 & 20.0 & 19.3 & 17.1\end{array}$


TABLE 10. Largemouth 8ass Mortalities During 96-hr Acute Toxicity Tests at $19^{\circ} \mathrm{C}$ with $\mathrm{Ch}$ loroform.

Test \#14 20 fish per aquarium

Census Times $12 \mathrm{hr} \quad 24 \mathrm{hr} \quad 48 \mathrm{hr} 96 \mathrm{hr}$

$\mathrm{CHCl}_{3}(\mathrm{ppm})$

$\begin{array}{ccccc}15.2 & 0 & 0 & 0 & 0 \\ 8.3 & 0 & 0 & 0 & 0 \\ 0.0 & 0 & 0 & 0 & 0 \\ 8.6 & 0 & 0 & 0 & 0 \\ 1.1 & 0 & 0 & 0 & 0 \\ 16.7 & 0 & 0 & 0 & 0\end{array}$

Test \#16 5 fish per aquarium Census Times $12 \mathrm{hr} \quad 24 \mathrm{hr} \quad 48 \mathrm{hr} \quad 96 \mathrm{hr}$ $\mathrm{CHCl}_{3}(\mathrm{ppm})$

$\tilde{\omega}$
Test \#17 5 fish per aquarium

Census Tímes $12 \mathrm{hr} 24 \mathrm{hr} 48 \mathrm{hr} 96 \mathrm{hr}$

$\mathrm{CHCl}_{3}(\mathrm{ppm})$

63.5

27.0

42.7

25.2

0.0

58.8

4
0
0
0
0
3

$\begin{array}{llll}4 & 4 & \mathrm{a} & \mathrm{a} \\ 0 & 0 & \mathrm{a} & \mathrm{a} \\ 0 & 0 & \mathrm{a} & \mathrm{a} \\ 0 & 0 & \mathrm{a} & \mathrm{a} \\ 0 & 0 & \mathrm{a} & \mathrm{a} \\ 3 & 3 & \mathrm{a} & \mathrm{a}\end{array}$

Test \#18 5 fish per aquarium Census Times $12 \mathrm{hr} \quad 24 \mathrm{hr} \quad 48 \mathrm{hr} \quad 96 \mathrm{hr}$ $\mathrm{CHCl}_{3}(\mathrm{ppm})$

$\begin{array}{rllll}36.7 & 0 & 0 & 0 & 0 \\ 55.9 & 5 & 5 & 5 & 5 \\ 48.0 & 1 & 1 & 1 & 1 \\ 77.8 & 5 & 5 & 5 & 5 \\ 0.0 & 0 & 0 & 0 & 0 \\ 77.1 & 5 & 5 & 5 & 5\end{array}$

a Test terminated due to chloroform pump failure. 
TABLE 10. (cont d)

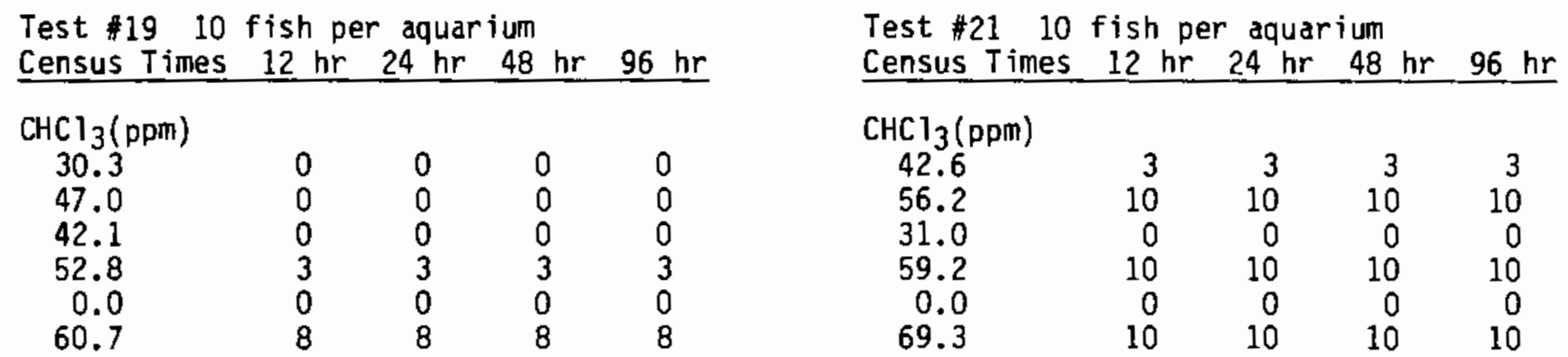

Test \#20 $10 \mathrm{fish}$ per aquarium

Census Times $12 \mathrm{hr} \quad 24 \mathrm{hr} \quad 48 \mathrm{hr} 96 \mathrm{hr}$

$\mathrm{CHCl}_{3}(\mathrm{ppm})$

$\begin{array}{rrrrr}20.0 & 0 & 0 & 0 & \mathrm{~b} \\ 39.0 & 0 & 0 & 0 & \mathrm{~b} \\ 37.2 & 0 & 0 & 0 & \mathrm{~b} \\ 47.3 & 1 & 1 & 1 & \mathrm{~b} \\ 0.0 & 0 & 0 & 0 & \mathrm{~b} \\ 61.7 & 10 & 10 & 10 & \mathrm{~b}\end{array}$

b Bioassay terminated prior to $72 \mathrm{hrs}$ due to disease mortality in the control aquarium. 
TABLE 11. Channel Catfish Mortalities During 96-hr Acute Toxicity Tests with Chloroform.

Test \#11 3 fish per aquarium

Census Times $12 \mathrm{hr} 24 \mathrm{hr} 48 \mathrm{hr} 96 \mathrm{hr}$

$\mathrm{CHCl}_{3}(\mathrm{ppm})$

$\begin{array}{cccc}12.3 & 0 & 0 & \text { a } \\ 12.1 & 0 & 0 & \text { a } \\ 0 & 0 & 0 & \text { a } \\ 6.1 & 0 & 0 & \text { a } \\ 3.7 & 0 & 0 & \text { a } \\ 14.4 & 0 & 0 & \text { a }\end{array}$

Test \#22 ( 1 fish per aquarium)

Census Times $12 \mathrm{hr} 24 \mathrm{hr} \quad 48 \mathrm{hr} \quad 96 \mathrm{hr}$

$\mathrm{CHCl}_{3}(\mathrm{ppm})$

$\underline{\omega}$

$$
39.8
$$

41.2

67.4

0

67.8

$\begin{array}{lll}0 & 0 & 0 \\ 0 & 0 & 0 \\ 0 & 0 & 0 \\ 0 & 0 & 0 \\ 0 & 0 & 0 \\ 0 & 0 & 0\end{array}$

Test \#25 5 fish per aquarium Census Times $12 \mathrm{hr} \quad 24 \mathrm{hr} \quad 48 \mathrm{hr} \quad 96 \mathrm{hr}$ $\mathrm{CHC}]_{3}(\mathrm{ppm})$

$\begin{array}{ccccc}42.1 & 0 & 0 & 0 & 0 \\ 69.7 & 0 & 0 & 0 & 0 \\ 0 & 0 & 0 & 0 & 0 \\ 31.7 & 0 & 0 & 0 & 0 \\ 49.4 & 0 & 0 & 0 & 0 \\ 42.4 & 0 & 0 & 0 & 0\end{array}$

Test \#26 10 fish per aquarium Census Times $12 \mathrm{hr} 24 \mathrm{hr} 48 \mathrm{hr} 96 \mathrm{hr}$

$\begin{array}{crrl}\mathrm{CHC1}_{3} \text { (ppm) } & & & \\ 92.3 & 0 & 0 & \mathrm{~b} \\ 171.0 & 10 & 10 & \mathrm{~b} \\ 0 & 0 & 0 & \mathrm{~b} \\ 166.3 & 10 & 10 & \mathrm{~b} \\ 108.9 & 0 & 0 & \mathrm{~b} \\ 65.0 & 0 & 0 & \mathrm{~b}\end{array}$

Test \#27 10 fish per aquarium Census Times $12 \mathrm{hr} \quad 24 \mathrm{hr} \quad 48 \mathrm{hr} 96 \mathrm{hr}$

$\begin{array}{crrrr}\mathrm{CHCl}_{3} \text { (ppm) } & & & & \\ 92.7 & 1 & 1 & 4 & 10 \mathrm{c} \\ 152.6 & 10 & 10 & 10 & 10 \mathrm{c} \\ 0 & 0 & 0 & 0 & 0 \mathrm{c} \\ 154.8 & 9 & 10 & 10 & 10 \mathrm{c} \\ 122.3 & 4 & 4 & 7 & 10 \mathrm{c} \\ 142.1 & 9 & 9 & 9 & 10 \mathrm{c}\end{array}$

Test $\# 2810$ fish per aquarium Census Times $12 \mathrm{hr} \quad 24 \mathrm{hr} \quad 48 \mathrm{hr} \quad 96 \mathrm{hr}$

$\begin{array}{ccccc}\mathrm{CHCl}_{3}(\mathrm{ppm}) & & & & \\ 68.2 & 0 & 0 & 0 & 1 \\ 88.9 & 0 & 0 & 2 & 7 \\ 0 & 0 & 0 & 0 & 0 \\ 78.8 & 0 & 0 & 0 & 5 \\ 76.0 & 0 & 0 & 0 & 6 \\ 82.3 & 0 & 0 & 0 & 6\end{array}$

a Test terminated at $48 \mathrm{hr}$ due to agressive fish behavior.

b Test terminated due to malfunction in toxicant delivery.

c Test terminated at $72-\mathrm{hr}$ census time. 
TABLE 12. Rainbow Trout Mortalities During 96-hr Acute Toxicity Tests with Chloroform.

Test \#5 10 fish per aquarium

Census Times $12 \mathrm{hr} \quad 24 \mathrm{hr} \quad 48 \mathrm{hr} \quad 96 \mathrm{hr}$

$\mathrm{CHCl}_{3}(\mathrm{ppm})$

$\begin{array}{rrrrr}20.0 & 0 & 0 & 1 & 7 \\ 11.3 & 0 & 0 & 0 & 0 \\ 12.0 & 0 & 0 & 0 & 0 \\ 13.2 & 0 & 0 & 0 & 0 \\ 0.0 & 0 & 0 & 0 & 0 \\ 22.9 & 0 & 1 & 9 & 10\end{array}$

Test 10 fish per aquarium Census Times $12 \mathrm{hr} \quad 24 \mathrm{hr} \quad 48 \mathrm{hr} \quad 96 \mathrm{hr}$

$$
\mathrm{CHCl}_{3}(\mathrm{ppm})
$$

$\begin{array}{rllll}19.5 & 0 & 0 & 5 & 7 \\ 15.4 & 0 & 8 & 8 & 8 \\ 15.0 & 0 & 0 & 0 & 0 \\ 16.6 & 0 & 0 & 0 & 0 \\ 0.0 & 0 & 0 & 0 & 0 \\ 25.5 & 0 & 1 & 1 & 7\end{array}$

Test \#7 20 fish per aquarium Census Times $12 \mathrm{hr} \quad 24 \mathrm{hr} \quad 48 \mathrm{hr} \quad 96 \mathrm{hr}$

$\begin{array}{crrrr}\mathrm{CHCl}_{3} \text { (ppm) } & & & & \\ 27.0 & 3 & 13 & 19 & 19 \\ 19.6 & 0 & 0 & 0 & 4 \\ 15.1 & 0 & 0 & 0 & 0 \\ 10.6 & 0 & 0 & 0 & 0 \\ 0.0 & 0 & 0 & 0 & 0 \\ 27.8 & 1 & 11 & 16 & 20\end{array}$

Test \#13 20 fish per aquarium

Census Times $12 \mathrm{hr} \quad 24 \mathrm{hr} \quad 48 \mathrm{hr} \quad 96 \mathrm{hr}$

$\begin{array}{crrrr}\mathrm{CHCl}_{3}(\mathrm{ppm}) & & & & \\ 18.6 & 0 & 0 & 10 & 17 \\ 8.4 & 0 & 0 & 0 & 0 \\ 3.3 & 0 & 0 & 0 & 0 \\ 12.3 & 0 & 0 & 3 & 6 \\ 0.0 & 0 & 0 & 0 & 0 \\ 12.1 & 0 & 0 & 0 & 0\end{array}$

Test \#15 20 fish per aquarium Census Times $12 \mathrm{hr} 24 \mathrm{hr} 48 \mathrm{hr} 96 \mathrm{hr}$

$\begin{array}{crrrr}\mathrm{CHC}_{3}(\mathrm{ppm}) & & & & \\ 26.6 & 15 & 20 & 20 & 20 \\ 9.8 & 0 & 0 & 0 & 0 \\ 15.3 & 0 & 0 & 0 & 0 \\ 18.6 & 0 & 0 & 3 & 19 \\ 0.0 & 0 & 0 & 0 & 0 \\ 20.6 & 3 & 16 & 20 & 20\end{array}$


TABLE 13. Bluegill Mortalities During 96-hr Acute Toxicity Tests with Chloroform.

Test \#2 10 fish per aquarium

Census Times $12 \mathrm{hr} 24 \mathrm{hr} \quad 48 \mathrm{hr} 96 \mathrm{hr}$

$\mathrm{CHCl}_{3}(\mathrm{ppm})$

$\begin{array}{rrrrr}2.4 & 0 & 0 & 0 & 0 \\ 0.4 & 0 & 0 & 0 & 0 \\ 3.0 & 0 & 0 & 0 & 0 \\ 13.7 & 1 & 1 & 1 & 1 \\ 0.0 & 0 & 0 & 0 & 0 \\ 21.4 & 9 & 9 & 10 & 10\end{array}$

Test \#3 10 fish per aquarium

Census Times $12 \mathrm{hr} \quad 24 \mathrm{hr} \quad 48 \mathrm{hr} \quad 96 \mathrm{hr}$

$\begin{array}{rrrrr}\mathrm{CHCl}_{3}(\mathrm{ppm}) & & & & \\ 18.7 & 0 & 0 & \mathrm{a} & \mathrm{a} \\ 14.1 & 1 & 1 & \mathrm{a} & \mathrm{a} \\ 16.3 & 1 & 1 & \mathrm{a} & \mathrm{a} \\ 14.5 & 0 & 1 & \mathrm{a} & \mathrm{a} \\ 0.0 & 0 & 0 & \mathrm{a} & \mathrm{a} \\ 23.9 & 6 & 8 & \mathrm{a} & \mathrm{a}\end{array}$

Test \#8 $5 \mathrm{fish}$ per aquarium Census Times $12 \mathrm{hr} 24 \mathrm{hr} \quad 48 \mathrm{hr} \quad 96 \mathrm{hr}$

$\begin{array}{rrrrr}\mathrm{CHCl}_{3}(\mathrm{ppm}) & & & & \\ 25.3 & 3 & 3 & 4 & 5 \\ 18.7 & 0 & 0 & 0 & 0 \\ 12.7 & 0 & 0 & 0 & 0 \\ 14.7 & 0 & 0 & 0 & 0 \\ 0.0 & 0 & 0 & 0 & 0 \\ 21.1 & 1 & 1 & 1 & 1\end{array}$

Test \#9 5 fish per aquarium

Census Times $12 \mathrm{hr} \quad 24 \mathrm{hr} \quad 48 \mathrm{hr} \quad 96 \mathrm{hr}$

$\begin{array}{rrrrr}\mathrm{CHCl}_{3}(\mathrm{ppm}) & & & & \\ 28.8 & 5 & 5 & 5 & 5 \\ 22.1 & 3 & 3 & 4 & 5 \\ 4.9 & 0 & 0 & 0 & 0 \\ 21.4 & 3 & 3 & 4 & 4 \\ 0.0 & 0 & 0 & 0 & 0 \\ 15.2 & 3 & 3 & 3 & 3\end{array}$

Test \#10 5 fish per aquarium Census Times $12 \mathrm{hr} \quad 24 \mathrm{hr} \quad 48 \mathrm{hr} \quad 96 \mathrm{hr}$

$\begin{array}{ccccc}\mathrm{CHCl}_{3}(\mathrm{ppm}) & & & & \\ 26.6 & 3 & 4 & 4 & 4 \\ 15.4 & 2 & 2 & 2 & 3 \\ 15.4 & 0 & 0 & 0 & 0 \\ 10.2 & 1 & 2 & 3 & 3 \\ 0.0 & 0 & 0 & 0 & 0 \\ 32.2 & 5 & 5 & 5 & 5\end{array}$

Test \#12 5 fish per aquarium

Census Times $12 \mathrm{hr} 24 \mathrm{hr} 48 \mathrm{hr} \quad 96 \mathrm{hr}$

$\begin{array}{rrrrr}\mathrm{CHCl}_{3}(\mathrm{ppm}) & & & & \\ 29.3 & 5 & 5 & 5 & 5 \\ 21.6 & 1 & 1 & 2 & 2 \\ 5.7 & 0 & 0 & 0 & 0 \\ 20.2 & 2 & 2 & 2 & 3 \\ 0.0 & 0 & 0 & 0 & 0 \\ 25.2 & 3 & 3 & 3 & 4\end{array}$

a Test terminated prior to $48-\mathrm{hr}$ census time due to mortality from columnaris disease in the control aquarium. 


\section{DISTRIBUTION}

No. of

Copies

OFFSITE

A. A. Churm

DOE Patent Division

9800 S. Cass Avenue

Argonne, IL 60439

10 Dr. Phillip R. Reed

Bob Samworth

John C. Lehr

U.S. Nuclear Regulatory Commission

7915 Eastern Avenue

Silver Springs, MD 20901

265 NRC Division of Technical Information and Document Control

Washington, DC 20555

2 DDE Technical Information Center

D. R. Anderson

2521 N. 40 th, No. 1

Seattle, WA 98103

Dr. Robert Broxton

Electric Power Research Inst itute

PO Box 10412

Palo Alto, CA 94303

Dr. Dennis T. Burton

Academy of Natural Sciences of Philadelphia

Benedict Estuarine Research Laboratory

Benedict, MD 20612
No. of

Copies

Dr. Will Davis

U.S.E.P.A.

Gulf Breeze Environmenta]

Research Laboratory

Wadmalaw Island, SC 19487

Dr. R. E, Hillman

W. F. Clapp Laboratories

Washington Street, P.0. Box AH

Duxbury, MA 02332

Dr. Donald Johnson

Dept. Environmental Sciences and Engineering School of Public Health

University of North Carolina

Chapel Hill, NC 27514

Dr. George R. Helz Chemistry Dept.

University of Maryland

College Park, MD 20742

Dr. Milton H. Lietzke

PO Box $X$

Oak Ridge National Laboratory

Oak Ridge, TN 37830

Dr. J. S. Mattice

PO Box $X$

Oak Ridge National Laboratory

Oak Ridge, TN 37830

Dr. John Lum

U.S.E.P.A.

401 M Street S.W.

WH552

Washington, DC 20460 
No. of

Copies

Dr. Roy Nakatan i

Dr. Quentin J. Stober

FRI WH-10

University of Washington

Seattle, WA 98195

Dr. Thomas 0. Thatcher

Rt 2 Box 113

Sequim, WA 98382

F. C. Tone

Florida Marine Research Facility

Sailfish Drive

Ponce Inlet

Daytona Beach, FL 32019

Ronald L. Raschke

U.S. EPA

S.E. Water Laboratory

Bailey Road

Athens, GA 30601
No. of

Copies

ONSITE

50 Pacific Northwest Laboratory

RM Bean (32)

CI Gibson

KE Harding (4)

DC Mann

TL Page

RG Riley

RE Schirmer

NM Sherer

RE Wildung

Publishing Coordination (2)

Technical Information (5) 



\begin{tabular}{|c|c|c|}
\hline \multirow{3}{*}{ 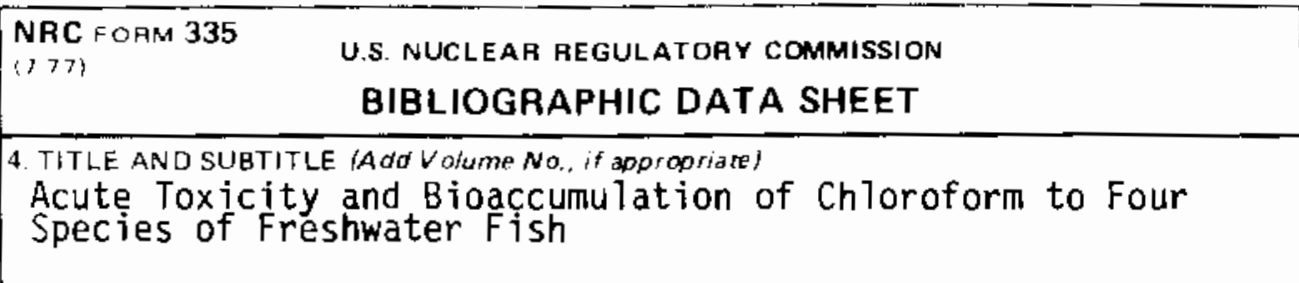 } & \multicolumn{2}{|c|}{$\begin{array}{l}\text { 1. AEPOHT NUMBER (Assigned by ODC) } \\
\text { NUREG /CR-0893 } \\
\text { PNL-3046 }\end{array}$} \\
\hline & \multicolumn{2}{|l|}{ 2. (Leave blank) } \\
\hline & \multicolumn{2}{|c|}{ 3. RECIPIENT'S ACCESSION NO. } \\
\hline \multirow{2}{*}{$\begin{array}{l}\text { 7. AUTHORisi } \\
\text { D.R. Anderson, E.B. Lusty }\end{array}$} & \multicolumn{2}{|c|}{ 5. DATE REPORT COMPLETED } \\
\hline & \multicolumn{2}{|c|}{\begin{tabular}{c|c}
$\begin{array}{c}\text { MONTH } \\
\text { July }\end{array}$ & YEAR \\
& 1980 \\
\end{tabular}} \\
\hline \multirow{3}{*}{$\begin{array}{l}\text { 9. PERFORMING ORGANIZATION NAME AND MAILING ADDRESS (Include Zip Codel } \\
\text { Pacific Northwest Laboratory } \\
\text { Richland, WA } 99352\end{array}$} & \multirow{2}{*}{\multicolumn{2}{|c|}{\begin{tabular}{l|l} 
DATE REPOHT ISSUED & \\
MONTH & YEAF \\
AuguSt & 1980 \\
\end{tabular}}} \\
\hline & & \\
\hline & \multicolumn{2}{|l|}{ 6. (Leave biank) } \\
\hline & \multicolumn{2}{|l|}{ 8. (Leave blank) } \\
\hline \multirow{2}{*}{$\begin{array}{l}\text { 12. SPONSORING ORGANIZATION NAME AND MAILING ADORESS (molude Zip Codel } \\
\text { Division of Safeguards, Fuel Cycle and Environmental Research } \\
\text { Office of Nuclear Regulatory Research } \\
\text { U.S. Nuclear Regulatory Commission } \\
\text { Washington, DC } 20555\end{array}$} & \multicolumn{2}{|c|}{ 10. PROJECTTTASK/WOHK UNIT NO. } \\
\hline & \multicolumn{2}{|c|}{$\begin{array}{l}\text { 11. CONT RACT NO. } \\
\text { FIN NO. B2098 }\end{array}$} \\
\hline \multicolumn{3}{|c|}{\begin{tabular}{|l|l|l|l|l|} 
13. TYPE OF REPORT & PE RIOD COVEREU (Incfusive dites)
\end{tabular}} \\
\hline 15. SUPPLEMENTARY NOTES & \multicolumn{2}{|l|}{ 14. (Leave olank) } \\
\hline \multicolumn{3}{|c|}{$\begin{array}{l}\text { 16. ABSTRACT (200words or tess) } \\
\text { Acute toxicity of chloroform to four species of freshwater fish was studied in } \\
\text { flow-through } 96-\mathrm{hr} \text { toxicity tests. Chloroform is toxic to fish in the tens of } \\
\text { parts per million, a concentration well above that which would be expected to } \\
\text { be produced under normal power plant chlorination conditions. Investigations } \\
\text { of acute toxicity of chlorof orm and the bioaccumulation of chlorinated } \\
\text { compounds in tissues of fish revealed differences in tolerance levels and } \\
\text { tissue accumulations. Mean } 96-h r \text { LC } 50 \text { for chloroform were } 18 \text { ppm for } \\
\text { rainbow trout and bluegill, } 51 \text { ppm for largemouth bass and } 75 \text { ppm for channel } \\
\text { catfish. Mortalities of bluegill and largemouth bass occurred during the } \\
\text { first } 4 \text { hr of exposure while rainbow trout and channel catfish showed initial } \\
\text { tolerance and mortalities occurred during the latter half of the } 96-h r \\
\text { exposure. Rainbow trout had the highest level of chloroform tissue } \\
\text { accumulation, } 7 \mu g / g \text { tissue, catfish the second highest, } 4 \mu g / g \text { tissue, } \\
\text { followed by bluegill and largemouth bass which each accumulated about } 3 \mu g / g \\
\text { tissue. Accumulation of chloroform was less than one order of magnitude above } \\
\text { water concentrations for all species. }\end{array}$} \\
\hline \multicolumn{3}{|c|}{ 17. KEY WORDS AND DOCUMENT ANAI YSIS } \\
\hline \multicolumn{3}{|c|}{17 IDENTIFIERS:OPEN-ENOED TEAMS } \\
\hline \multirow{2}{*}{$\begin{array}{l}\text { 18. AVAILABILITY STAIEMENT } \\
\text { Unlimited }\end{array}$} & \multirow{2}{*}{ 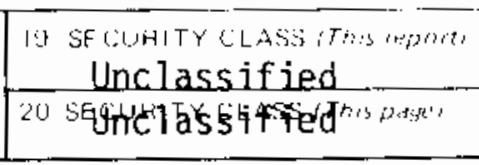 } & $21 \mathrm{NOO}$ Or PACit is \\
\hline & & 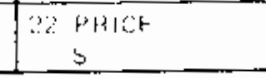 \\
\hline
\end{tabular}





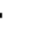

